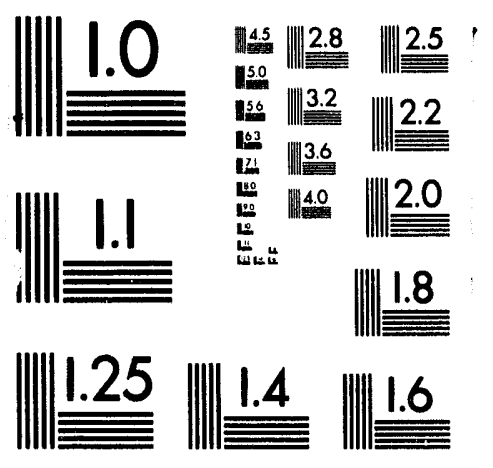



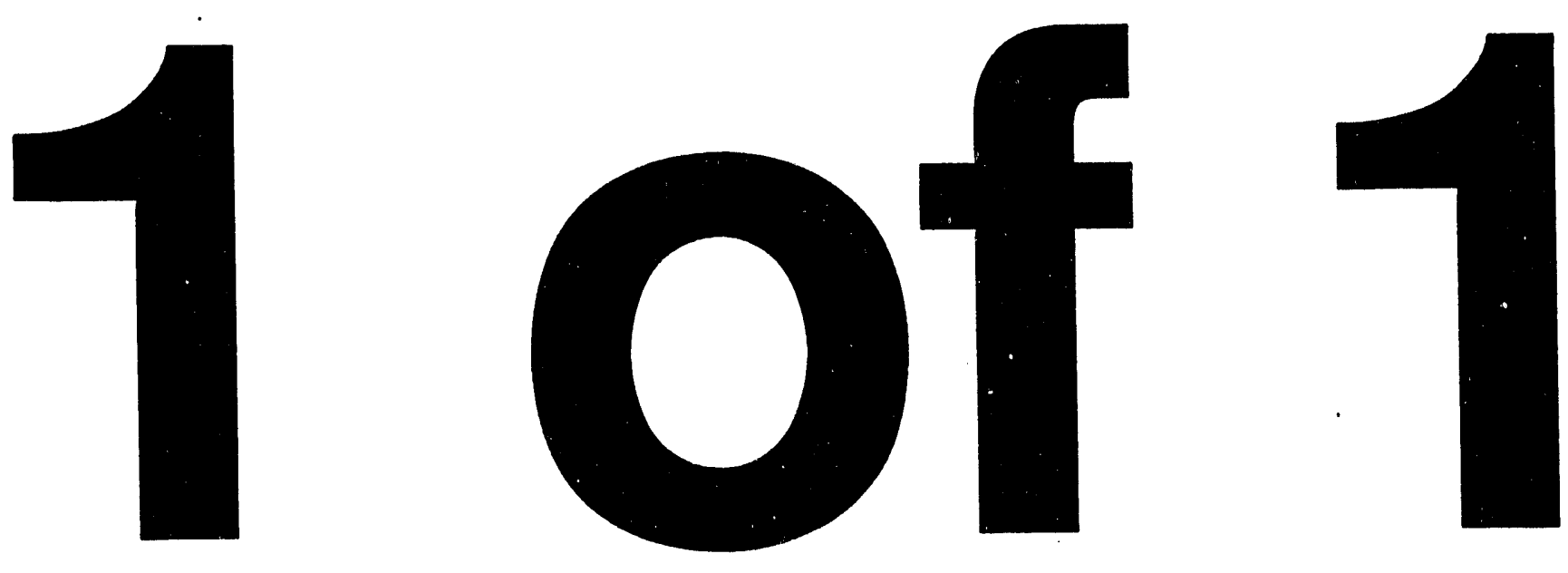
WHC-EP-0683

\title{
Adiabatic Calorimetry (RSST and VSP) Tests with Sodium Acetate
}

\author{
N. W. Kirch \\ Date Published \\ September 1993
}

Prepared for the U.S. Department of Energy Office of Environmental Restoration and Waste Management

\section{(W) Westinghouse P.O. Box 1970 Hantord Company Richland, Washington 99352 \\ Hanford Operations and Engineering Contractor for the \\ U.S. Department of Energy under Contract DE-AC06-87RL10930}




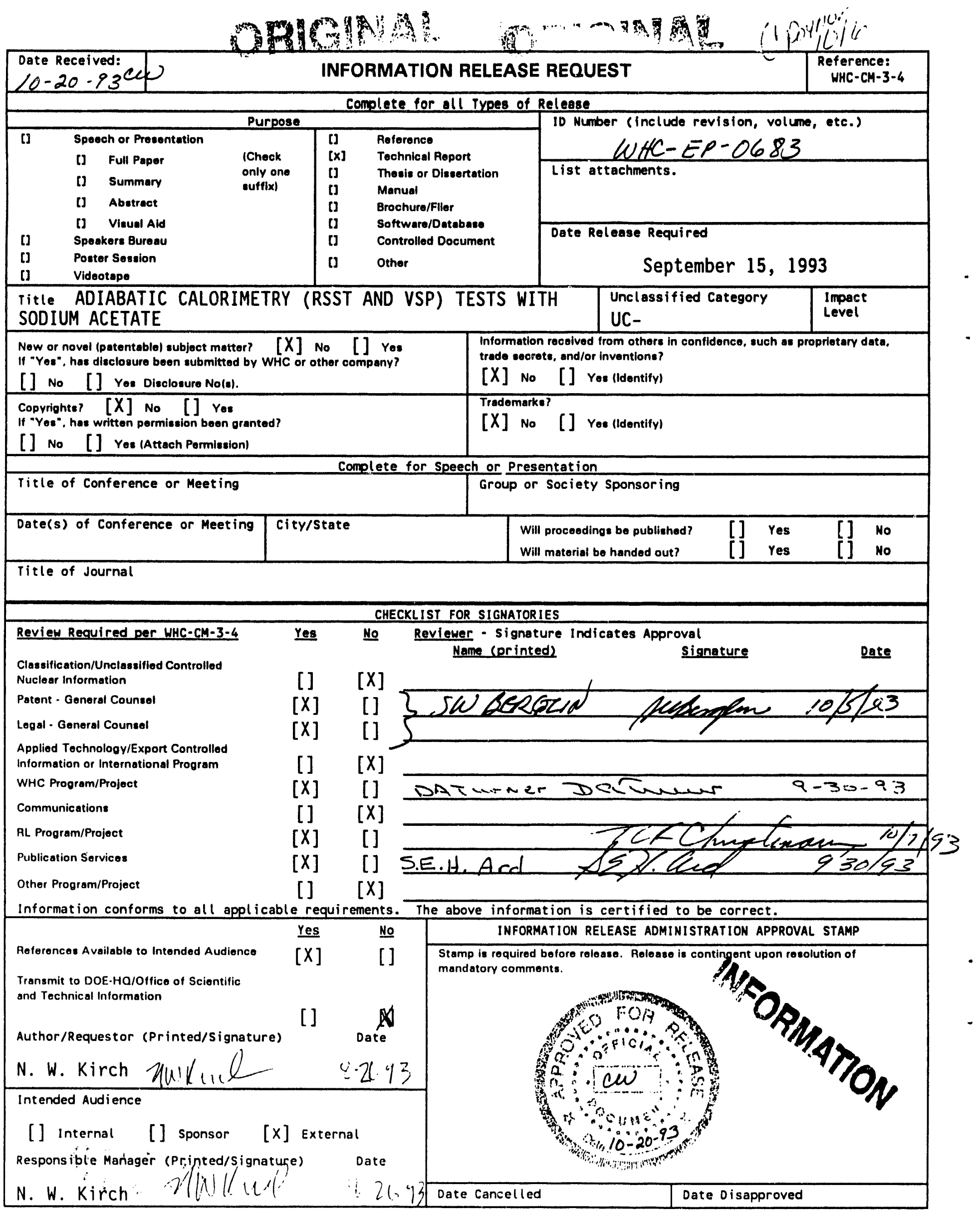




\section{WHC-EP-0683}

DATE: August 17, 1993

I0: Dave Turner, WHC

FROY: Hans Fauske, FAI

SUBJECT: Adiabatic Calorimetry (RSST and VSP) Tests with Sodium Acetate

REFERENCE: "Energetics of Organic Compounds in Single-Shell Tank Waste", Letter from R. J. Cash to H. K. Fauske dated May 5, 1993.

\section{Summary}

As requested in the subject reference, adiabatic calorimetry (RSST and VSP) tests have been performed with sodium acetate covering TOC concentrations from 3 to 78 with the following results:

- Exothermic activity noted around $200^{\circ} \mathrm{C}$.

- Propagating reaction initiated at about $300^{\circ} \mathrm{C}$. Required TOC concentration for propagation estimated at about 6 wo (dry mixture) or about 20 wo sodium acetate.

- Heat of reaction estimated to be $3.7 \mathrm{MJ}$ per $\mathrm{kg}$ of sodium acetate (based on VSP test with 3 wo TOC and using a dry mixture specific heat of $1000 \mathrm{~J} \mathrm{~kg}^{-1} \mathrm{~K}^{-1}$ ).

Based upon the above results we estimate that a moisture content in excess of 14 wo would prevent a propagating reaction of a stoichiometric mixture of fuel and oxidizer ( -38 wo sodium acetate and $\sim 62$ wo sodium nitrate). Assuming that the fuel can be treated as sodium acetate equivalent, and considering that the moisture content in the organic containing waste generally is believed to be in excess of $14 \mathrm{wz}$, it follows that the possibility of propagating reactions in the Hanford waste tanks can be ruled cut. 


\section{RSST - 7 wo TOC (Rectpe 3 in the Subject Refererice)}

A $9.75 \mathrm{gm} 7$ w8 TOC sample (24 w8 sodium acetate, 12 w8 sodium hydroxide, 51.4 wo sodium nitrate and 12.6 wo sodium nitrite) was ground using a mortar and pistol and sieved to a 140 Mesh (105 micron) in a dry nitrogen filled glove box. Note that reagents were newly required and of purity levels required to satisfy those specified in the subject reference. Following loading of the sample in the RSST, it was subjected to an external heating rate of approximately $1^{\circ} \mathrm{C} / \mathrm{min}$.

The measured RSST data are presented in Figures 1 through 5. An Arrhenius type reaction is apparent at about $200^{\circ} \mathrm{C}$ but changes to a propagating reaction at about $300^{\circ} \mathrm{C}$. The temperature jumps from $311^{\circ} \mathrm{C}$ to $363^{\circ} \mathrm{C}$ within one data point and then reaches a peak temperature of about $1067^{\circ} \mathrm{C}$ in the next point, $1.1 \mathrm{sec}$ later. The corresponding pressure spike is about 160 psig. Cooldown pressure indicates a net increase of about 44 psi.

Considering the measured temperature rise of about $867^{\circ} \mathrm{C}$ and setting the specific heat equal to $1000 \mathrm{~J} \mathrm{~kg}^{-1} \mathrm{k}^{-1}$, we calculate a heat of reaction of about $3.6 \mathrm{MJ}$ per $\mathrm{kg}$ of sodium acetate.

Moles of gas produced can be estimated from the measured RSST containment pressure increase (following cooldown) by

$$
\Delta n_{\text {moles }}=\frac{\Delta P V}{R T}
$$

$$
\text { where } \begin{aligned}
\Delta \mathrm{P}(\mathrm{atm}) & \text { - RSST containment pressure increase, } \\
\mathrm{V}(\ell) & \text { - RSST containment volume }(-0.35 \ell), \\
\mathrm{R}(\ell-\mathrm{atm} / \mathrm{K}-\mathrm{mole}) & \text { - gas constant }(0.08205), \text { and } \\
\mathrm{T}(\mathrm{K}) & \text { - cooldown temperature }(-295 \mathrm{~K}),
\end{aligned}
$$

and results in 0.044 moles of gas produced. This value is in good agreement with the calculated value $(-0.043)$ based on the assumption that one mole of sodium acetate produces 1.5 moles of gas 


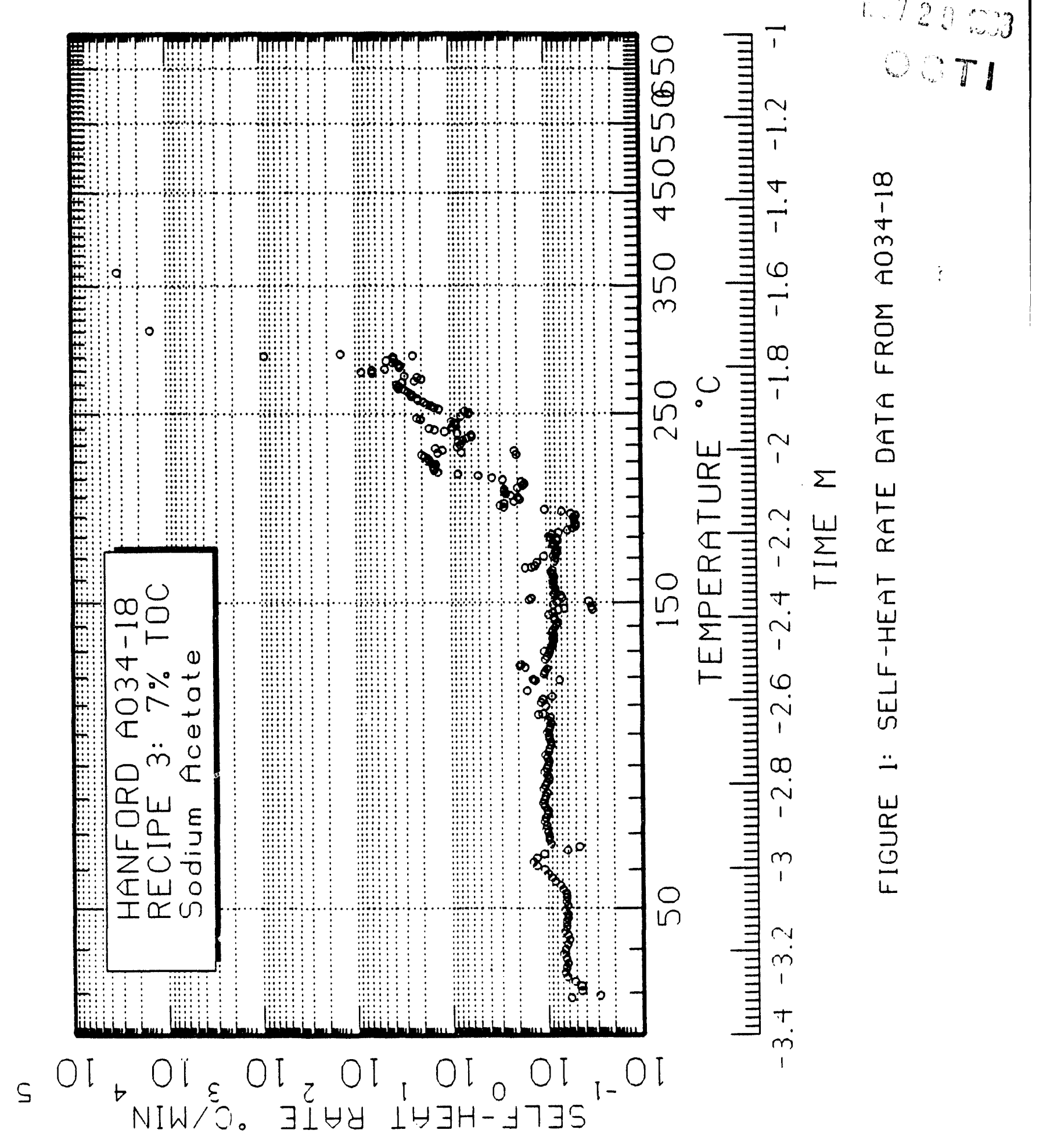




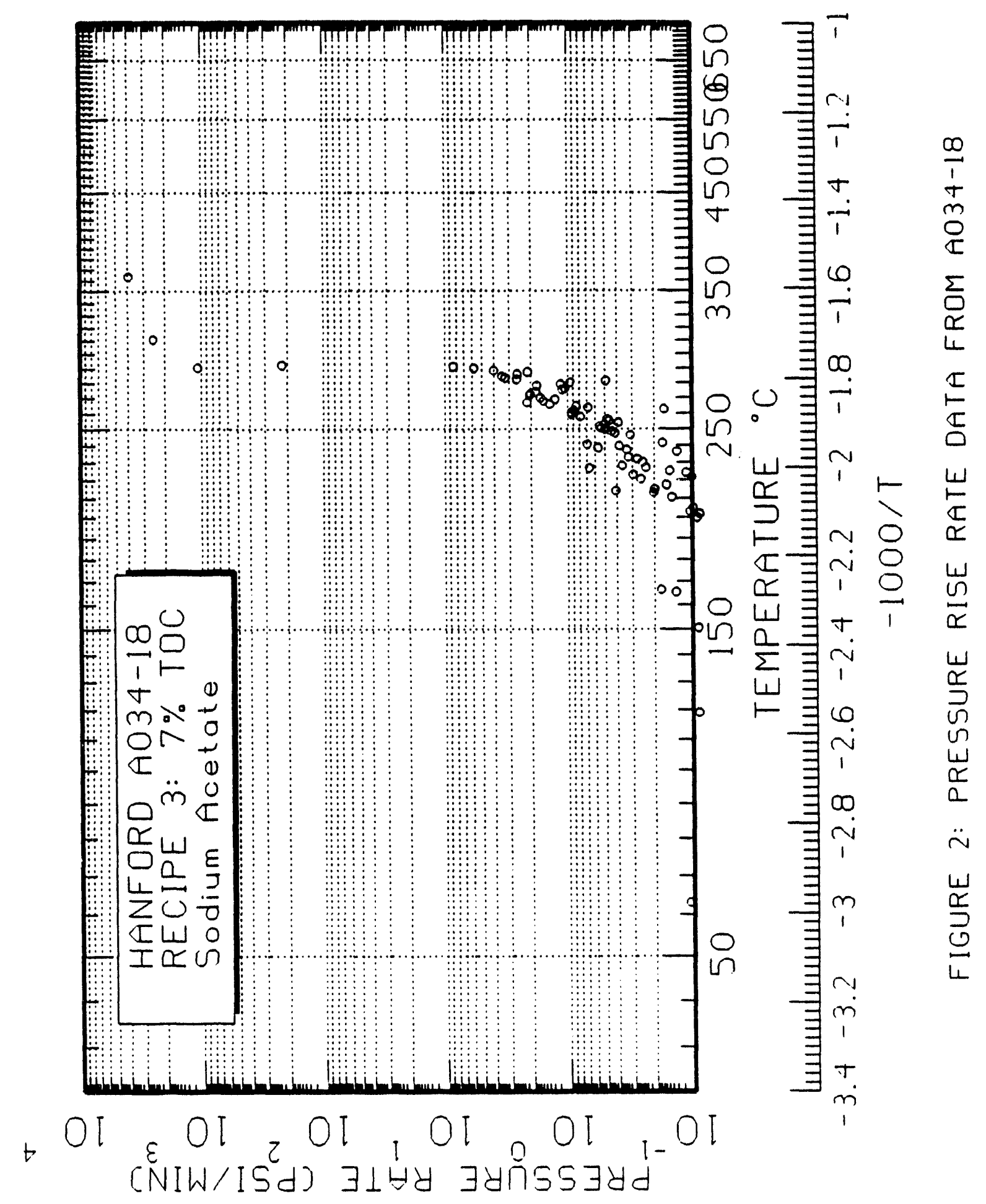




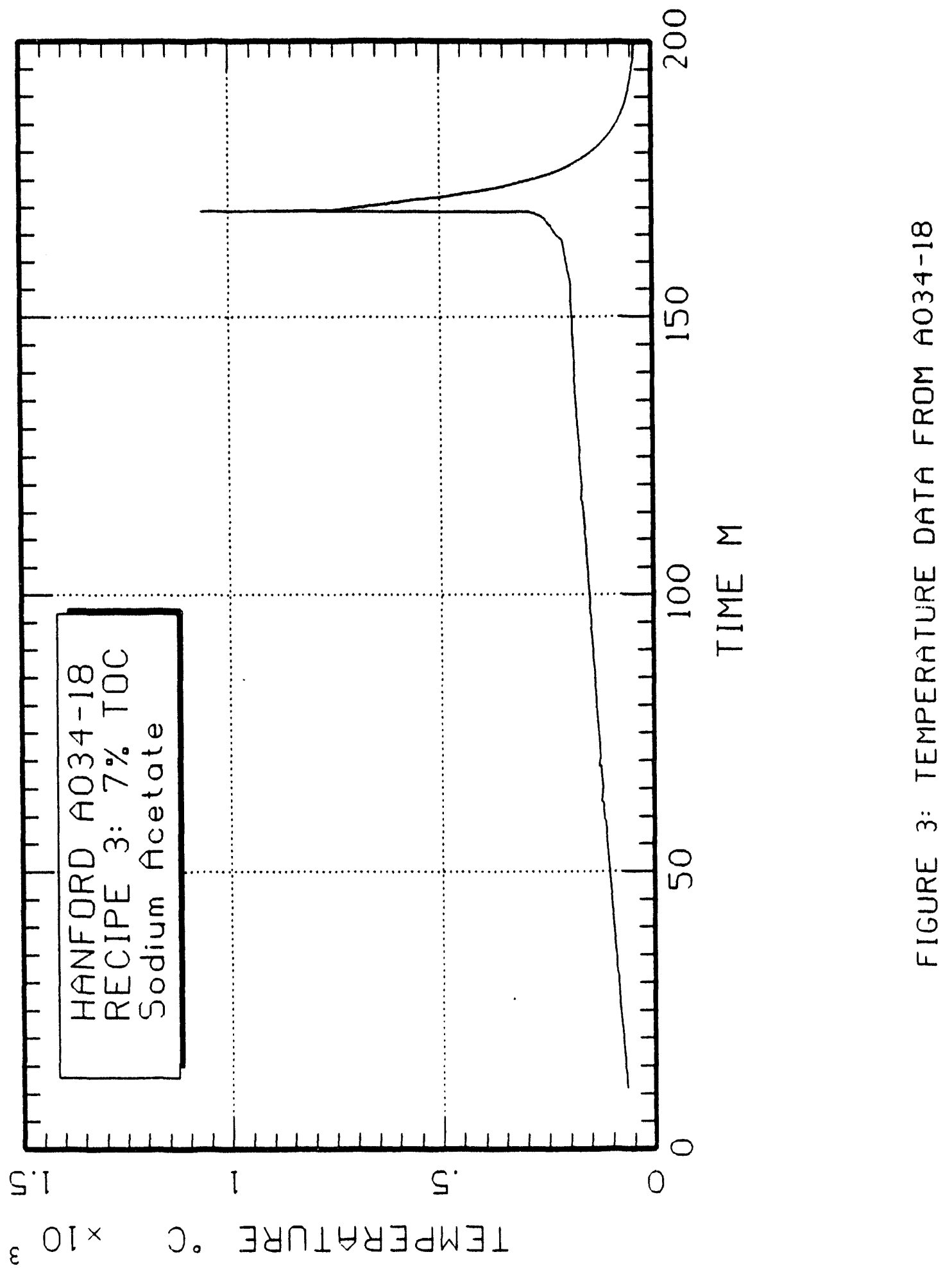




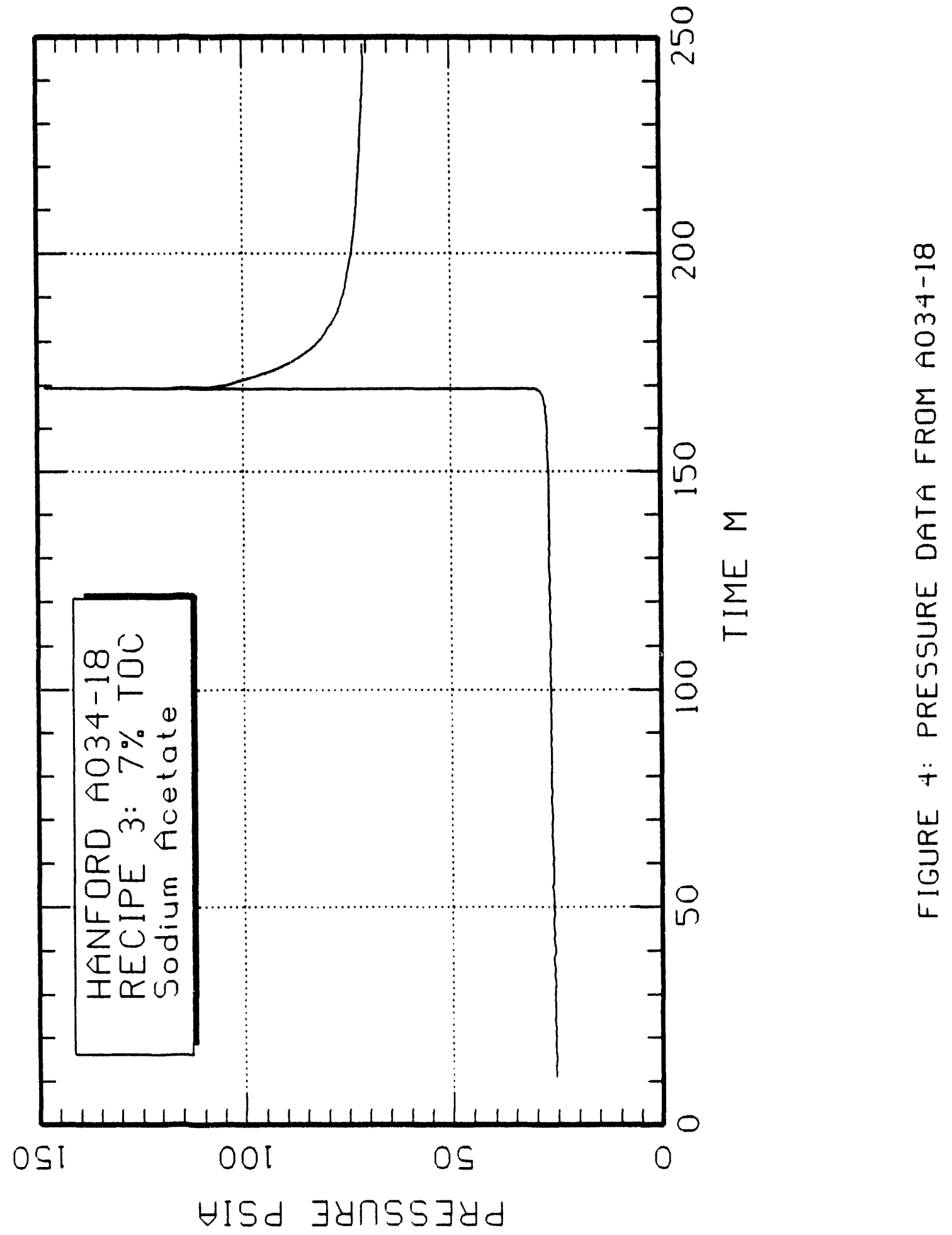




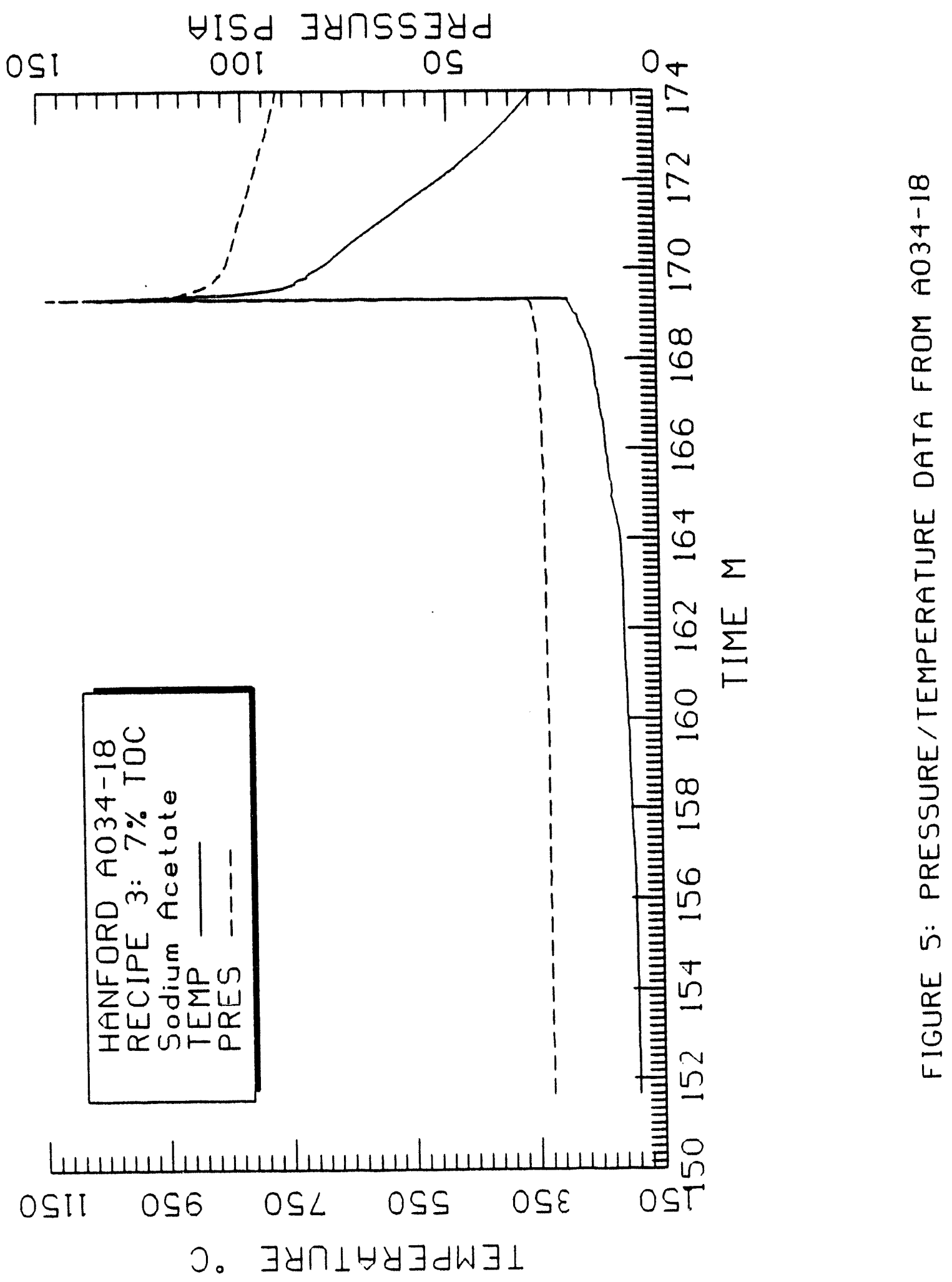




$$
\mathrm{NaC}_{2} \mathrm{H}_{3} \mathrm{O}+1.6 \mathrm{NaNO}_{3} \rightarrow 1.3 \mathrm{Na}_{2} \mathrm{CO}_{3}+1.5 \mathrm{H}_{2} \mathrm{O}+0.7 \mathrm{CO}_{2}+0.8 \mathrm{~N}_{2}
$$

Post test examination following cooldown indicates a reasonable violent reaction. The majorlty of the material in the test cell has been ejected from the cell. The containment walls are covered with a moist blackish film. Small hardenad "pools" of a slightly brownish white solid are found on the vessel 11d, floor, and on the insulation holder. In contrast to previous observations with propagating ferrocyanide reactions, the test cell is not broken. It contains only a small hardened pool of the brownish white solid at the bottom. The material has a lot of void space in 1t, suggesting that gas was being produced when it solidified. Overall good reproducibility of the above findings have bean demonstrated by performing duplicate tests. The measured cooldown pressures ranged from 40 to 45 psi.

\section{RSST - 5 w8 TOC (Reclpe 2 in the Subject Reference)}

A 9.97 gm 5 wo TOC sample (17.2 wo sodium acetate, 8.5 wo sodium hydroxide, 59.7 wo sodium nitrate, 14.6 wo sodium nitrite) was prepared and loaded in the RSST, using procedures similar to the RSST test - 7 wo TOC.

The measured RSST data are presented in Figures 6 through 10. Again, significant exothermic activity is noted close to $200^{\circ} \mathrm{C}$, but in contrast to the 7 wo TOC test, no apparent transition to a propagating reaction is observed, despite reaching a peak temperature of about $670^{\circ} \mathrm{C}$.

The above observation is consistent with the relatively lower measured cooldown pressure increase of about $8 \mathrm{psi}$, which is equivalent to about 0.008 moles of gas produced, as compared to a theoretical value of about 0.03 moles. Also consistent with these observations is the RSST measured temperature increase following exothermic activity of about $470^{\circ} \mathrm{C}$ which results in an equivalent heat of reaction of about $2.8 \mathrm{MJ}$ per $\mathrm{kg}$ of sodium acetate.

Post-test examination following cooldown again indicate that a significant fraction of the test cell contents were ejected. The vessel 


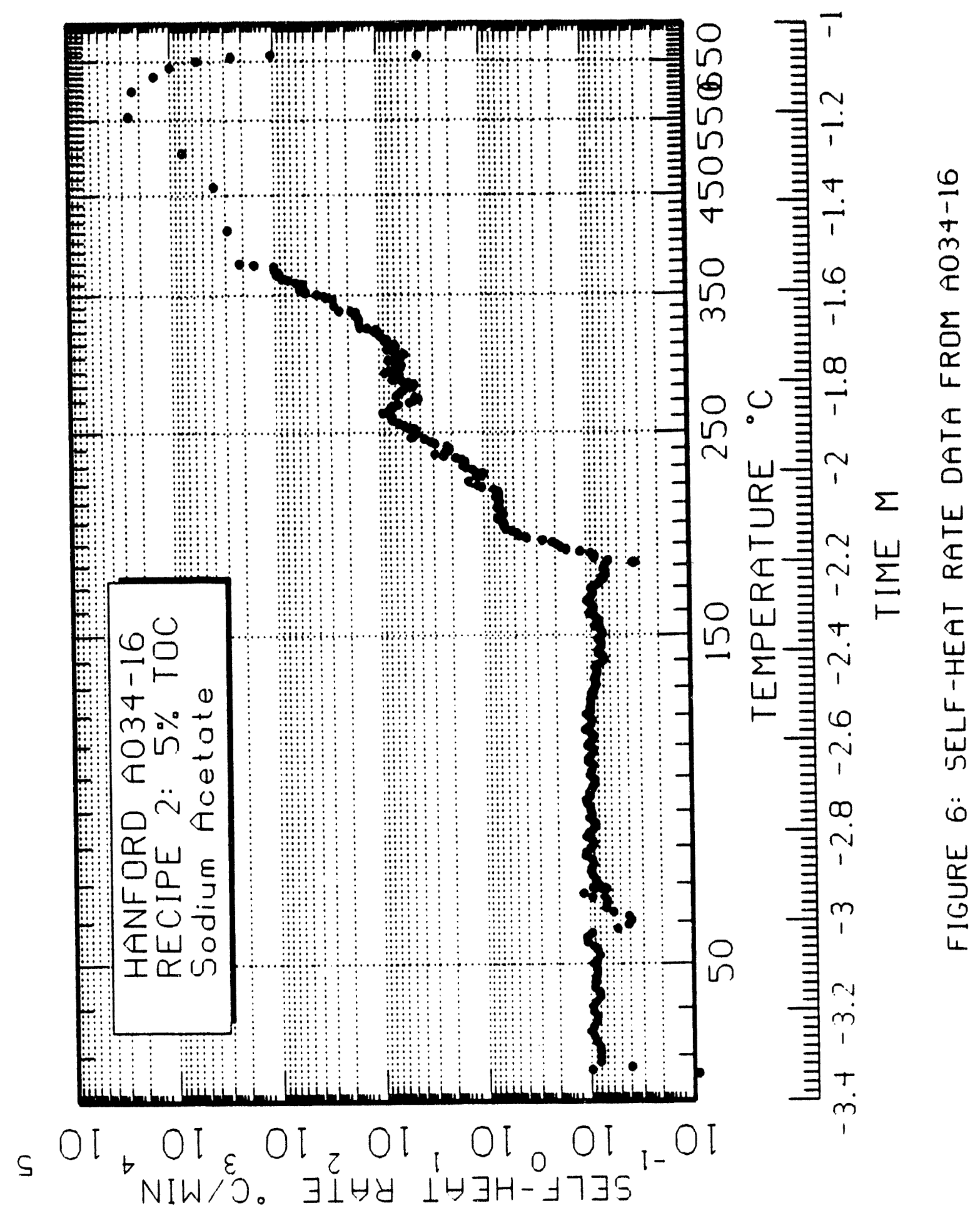




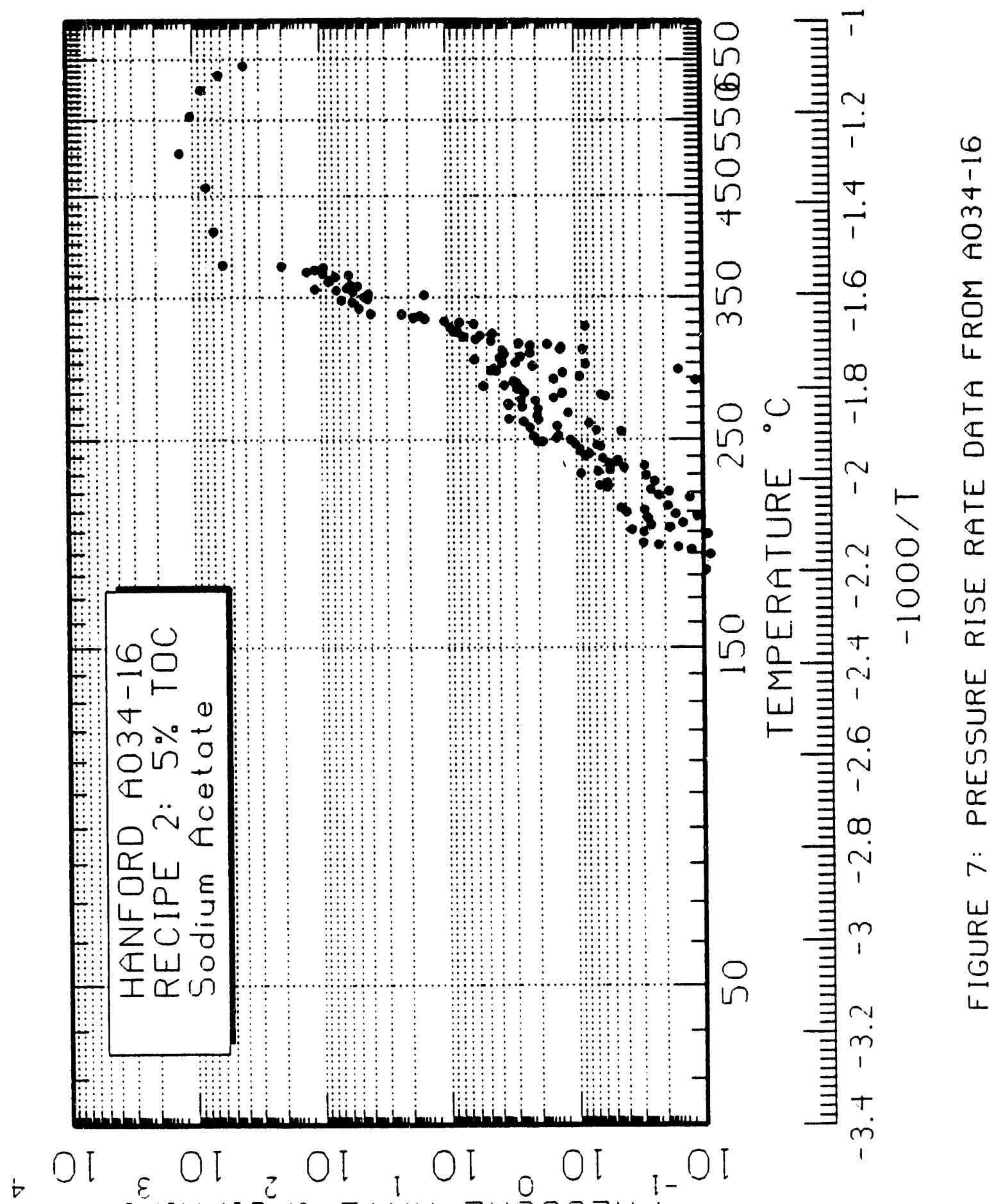
[NIW/IS'd] $\exists \perp \forall y \quad \exists y n s s \exists y d$ 


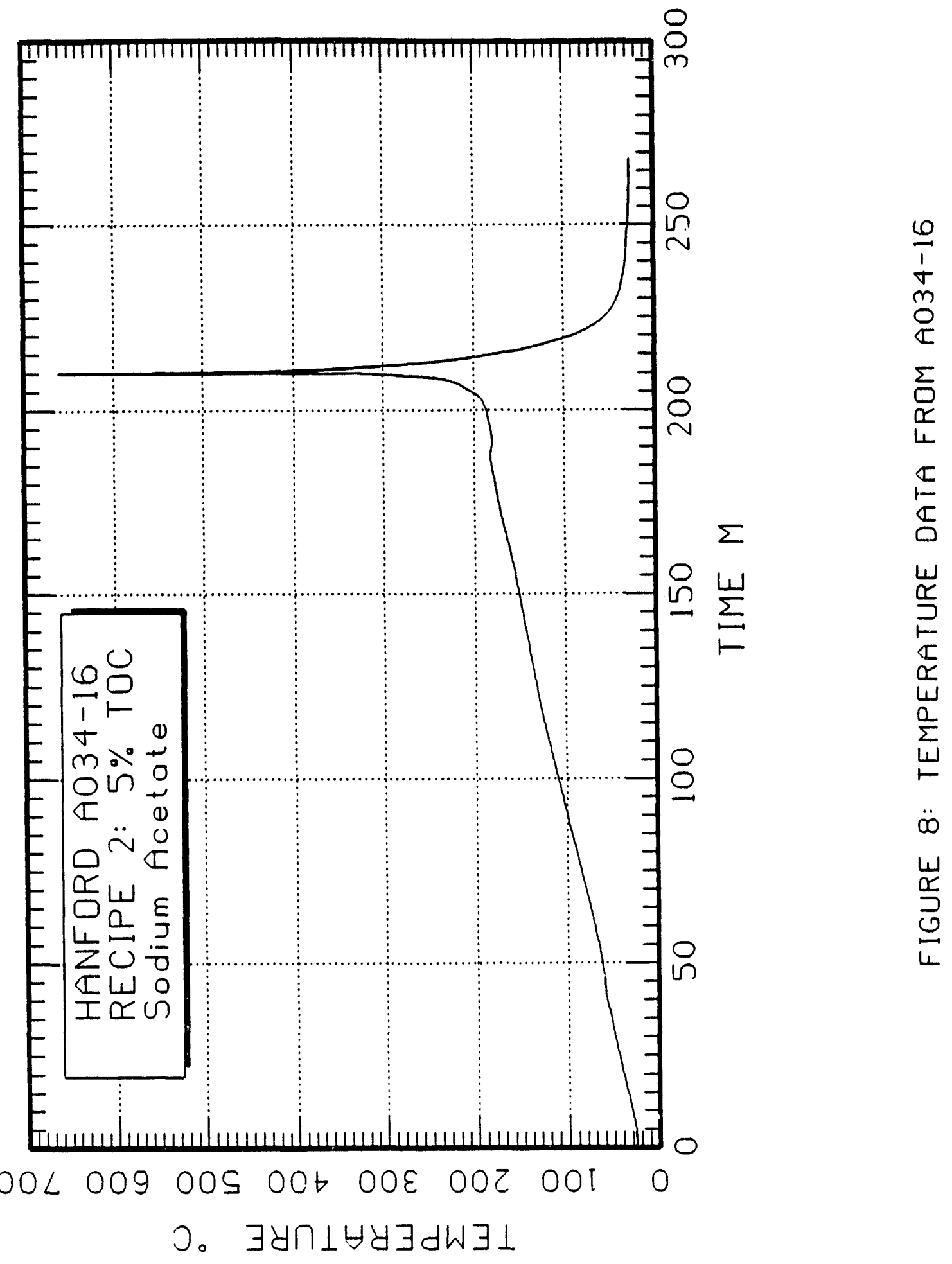




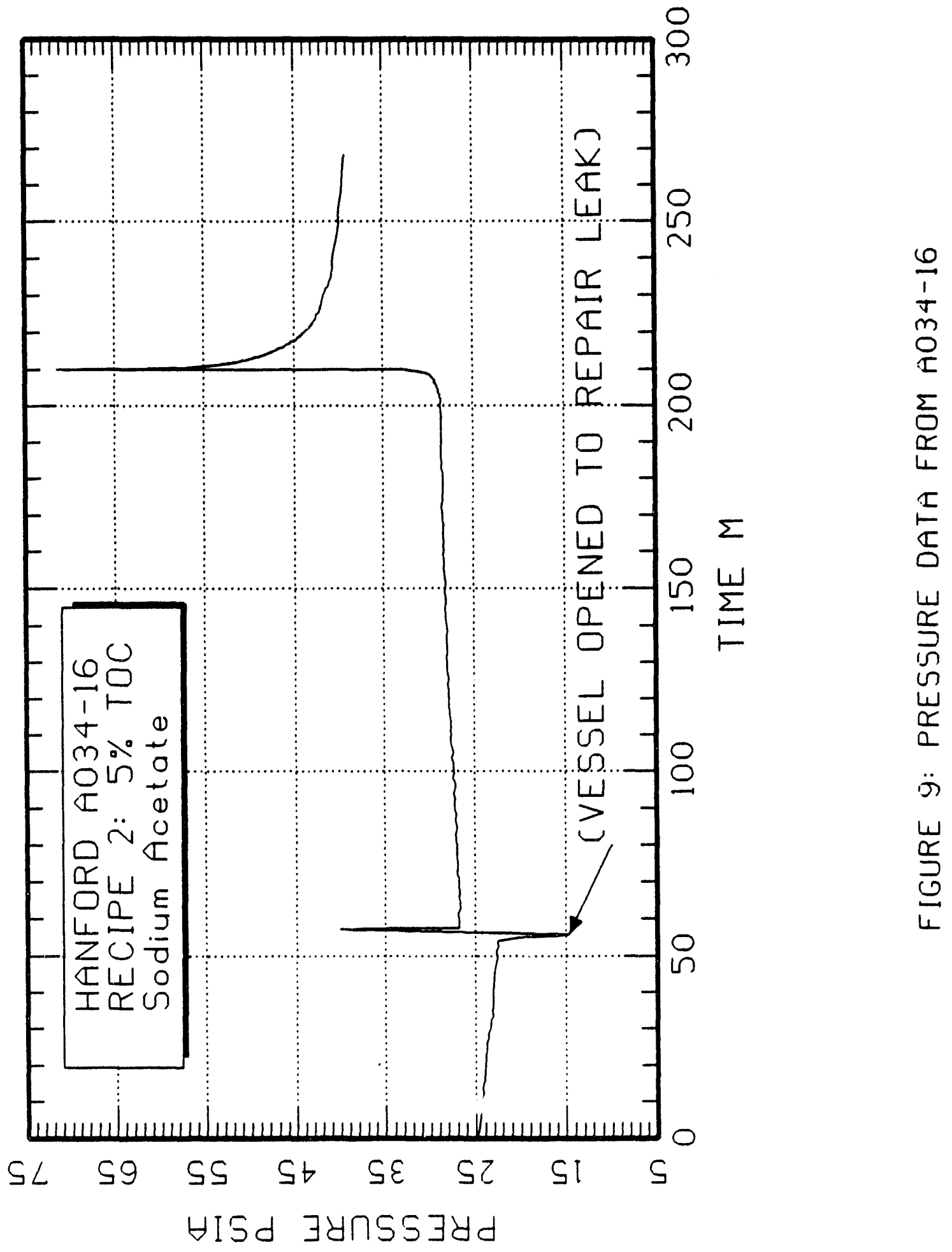


$\forall$ ISd $\exists$ UחSS $\exists$ dyd

SL OL S9 OS SS OS St Ob SE OE Sदn

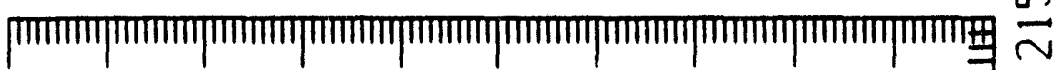

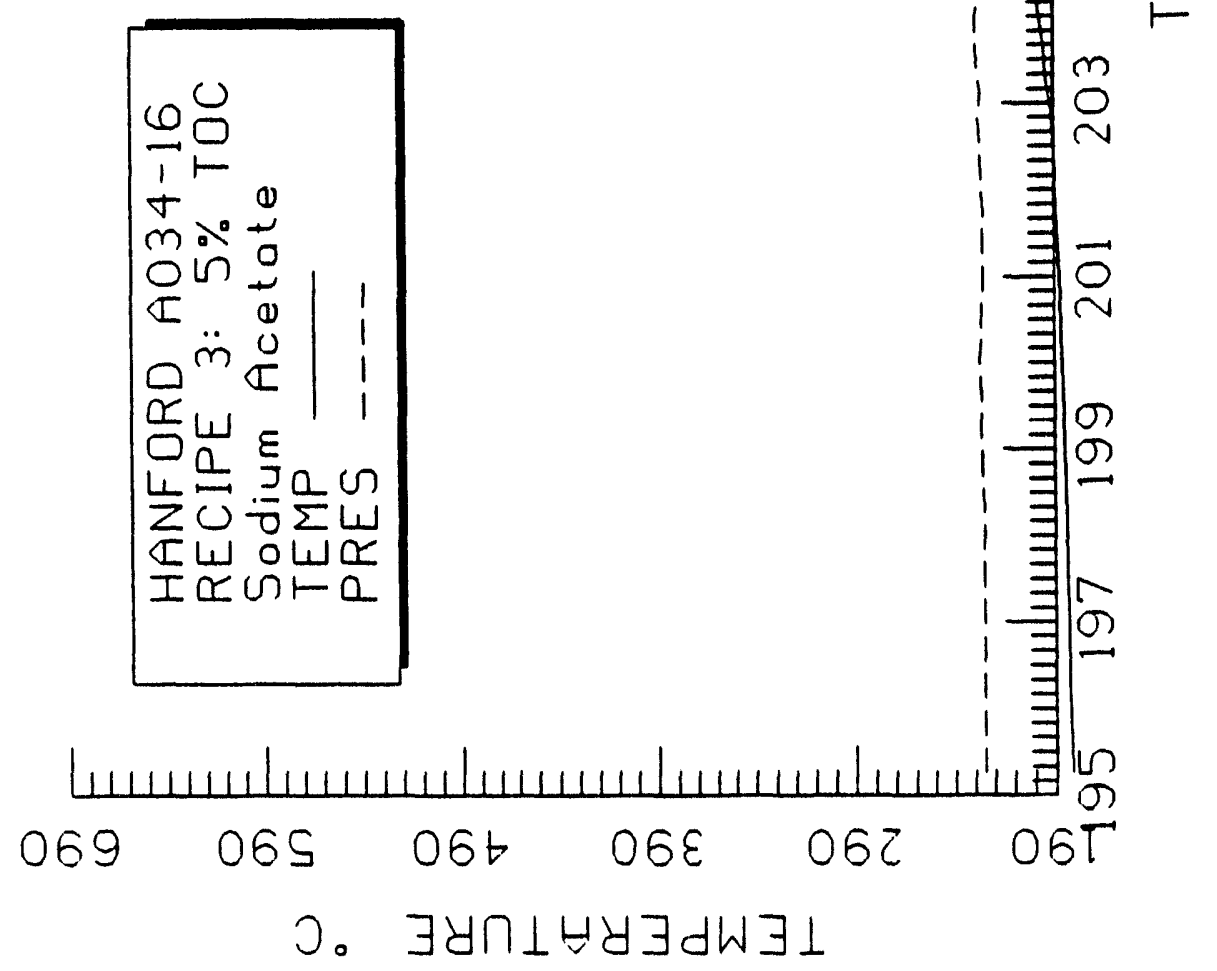


walls and 11d, however, were not covered with the moist black film that was noticed in previous 7 wo roc tests.

\section{RSST - $3.5 \mathrm{WB}$ TOC}

A $9.85 \mathrm{gm} 3.5$ wo TOC sample ( 11.8 wo sodium acetate, 8.5 w8 sodium hydroxide, 62.9 wo sodium nitrate and 16.8 wo $\mathrm{NaNO}_{2}$ ) was prepared and loaded in the RSST, using the same procedures as used for RSST test - 7 wo TOC.

The measured RSST data are presented in Figures 11 through 14 . Exothermic activity is indicated around a temperature of about $180^{\circ} \mathrm{C}$, although this indication may be due to the RSST overcompensating for an endotherm at the same temperature. Again, no apparent transition to a propagating reaction is observed. The net pressure gain following cooldown is about 5 psi which corresponds to about 0.005 moles of gas. This compares to the theoretical value of about 0.021 moles.

Post-test examination following cooldown showed similar behavior to that observed for RSST test - 5 wo TOC, 1.e., the absence of the moist black film that was noticed with 7 wo TOC tests.

\section{RSST - 3 w8 TOC (Recipe 1 in the subject Reference)}

A 9.90 gm 3 wo TOC sample (10.4 wo sodium acetate, 7.2 w8 sodium hydroxide, 67.8 wo sodium nitrate and 16.8 wo sodium nitrite) was prepared and loaded in the RSST, using the same procedures as described for the RSST test - 7 wo TOC.

The measured RSST data are presented in Figures 15 through 19. Exothermic activity is again indicated around $180^{\circ} \mathrm{C}$, although it is noted that this indication may be accelerated due to the RSST overcorrecting for a possible endotherm in the same temperature region. Again, no apparent transition to a propagating reaction is observed. The net pressure gain following cooldown is about 3 psi which corresponds to about 0.003 moles of gas produced. This compares to the theoretical value of about 0.019 moles. 


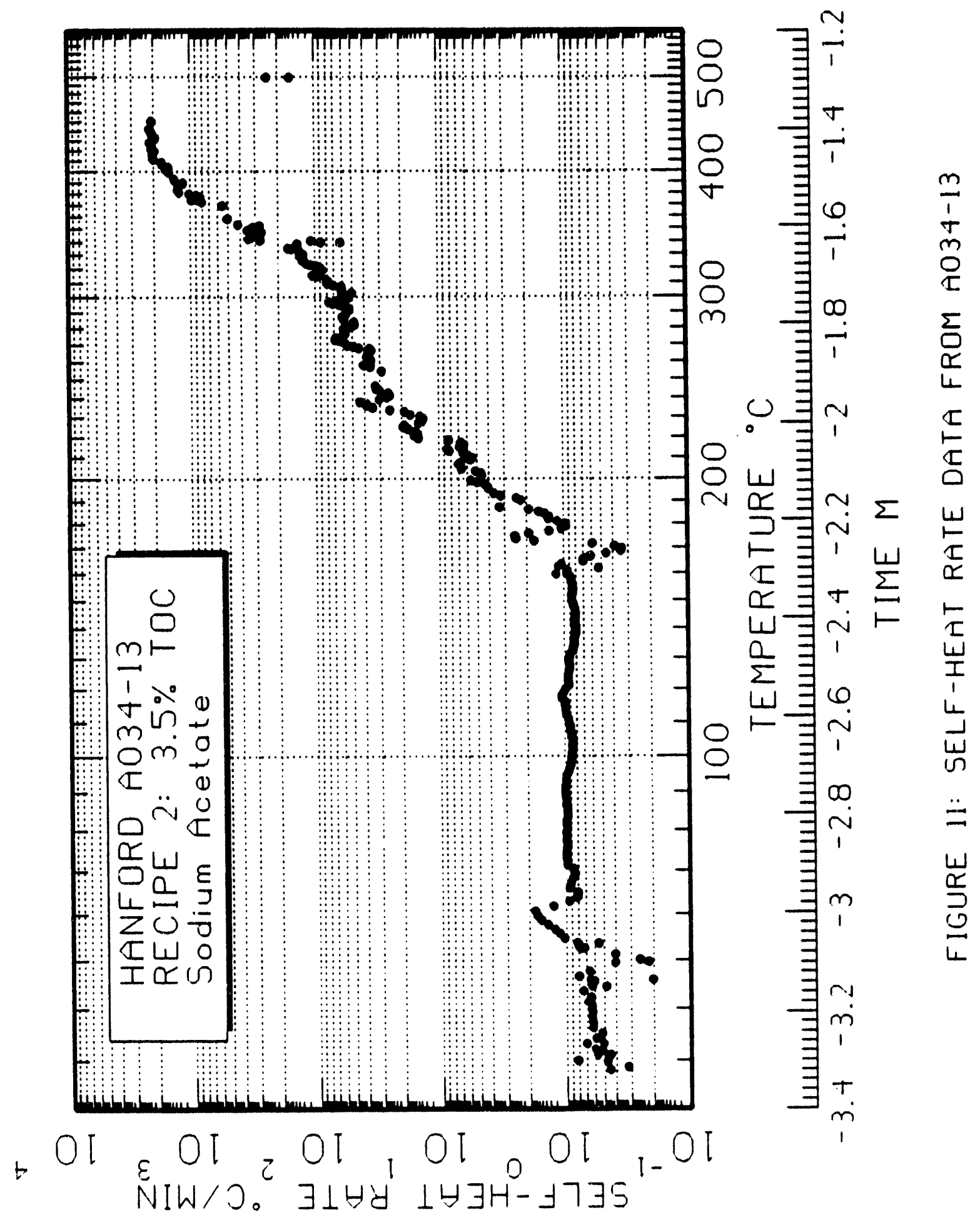




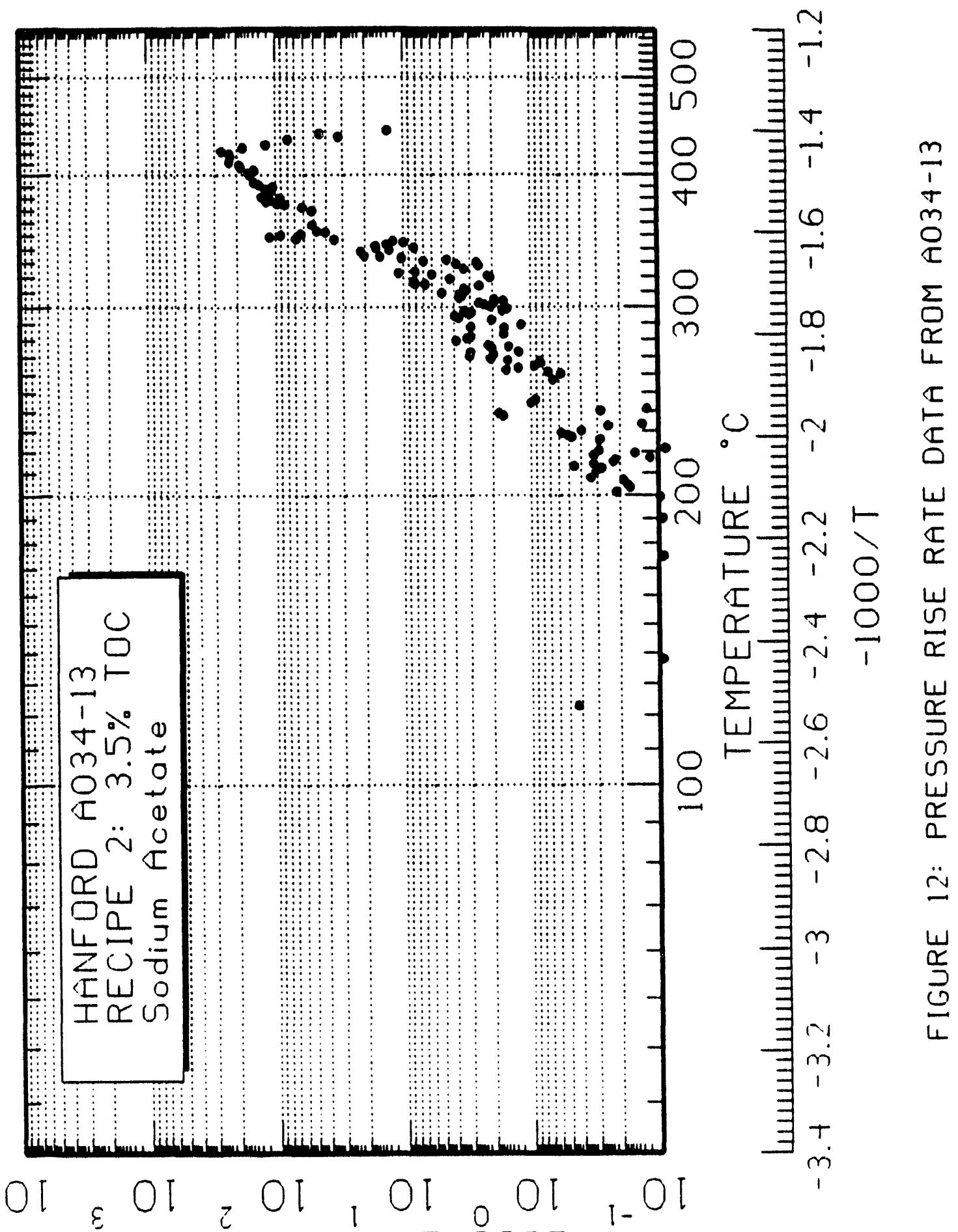

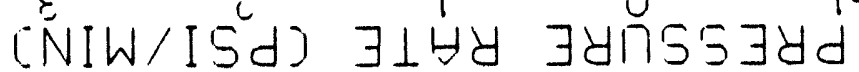




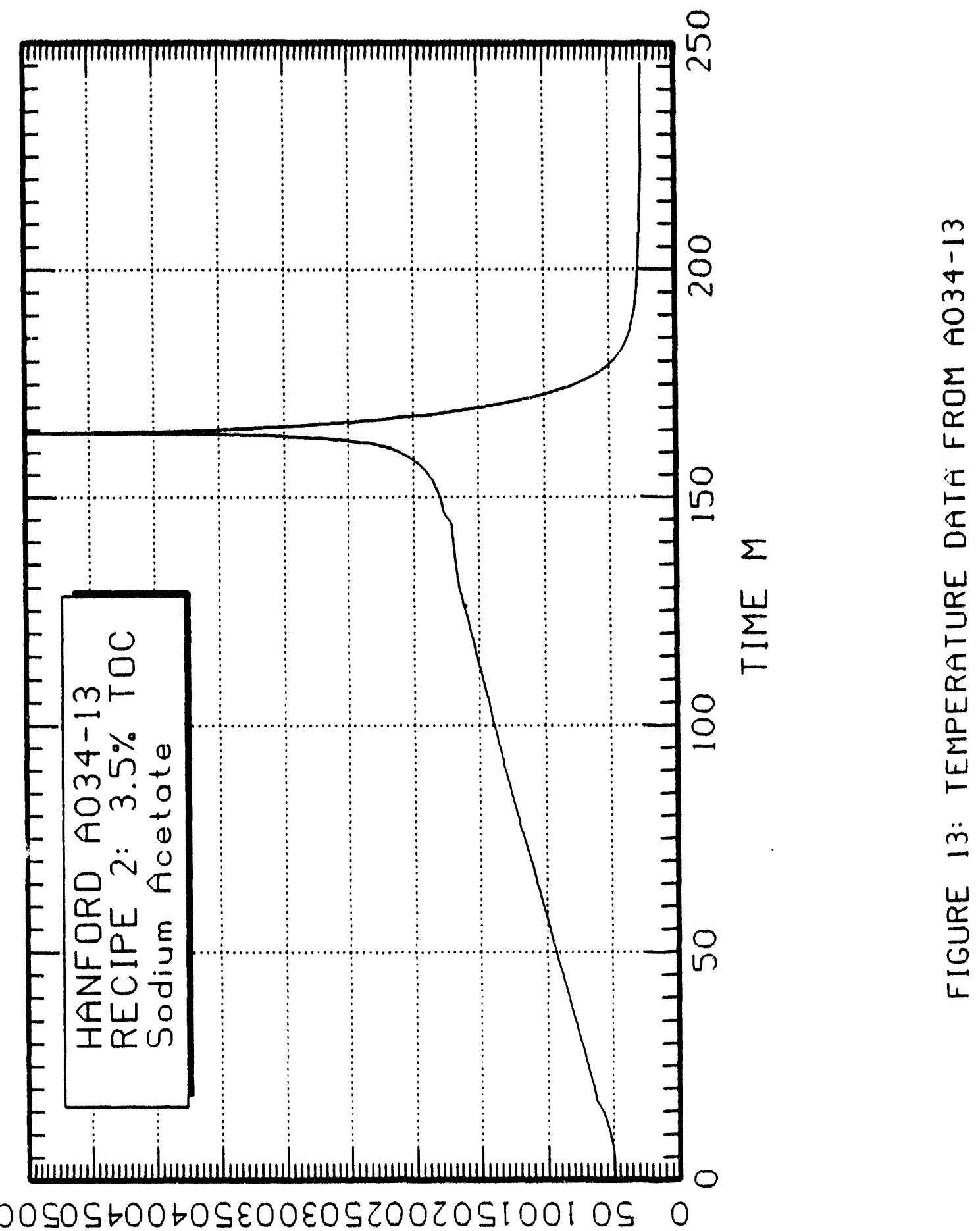

ว。 $\exists y \Pi \perp \forall y \exists d w \exists \perp$ 


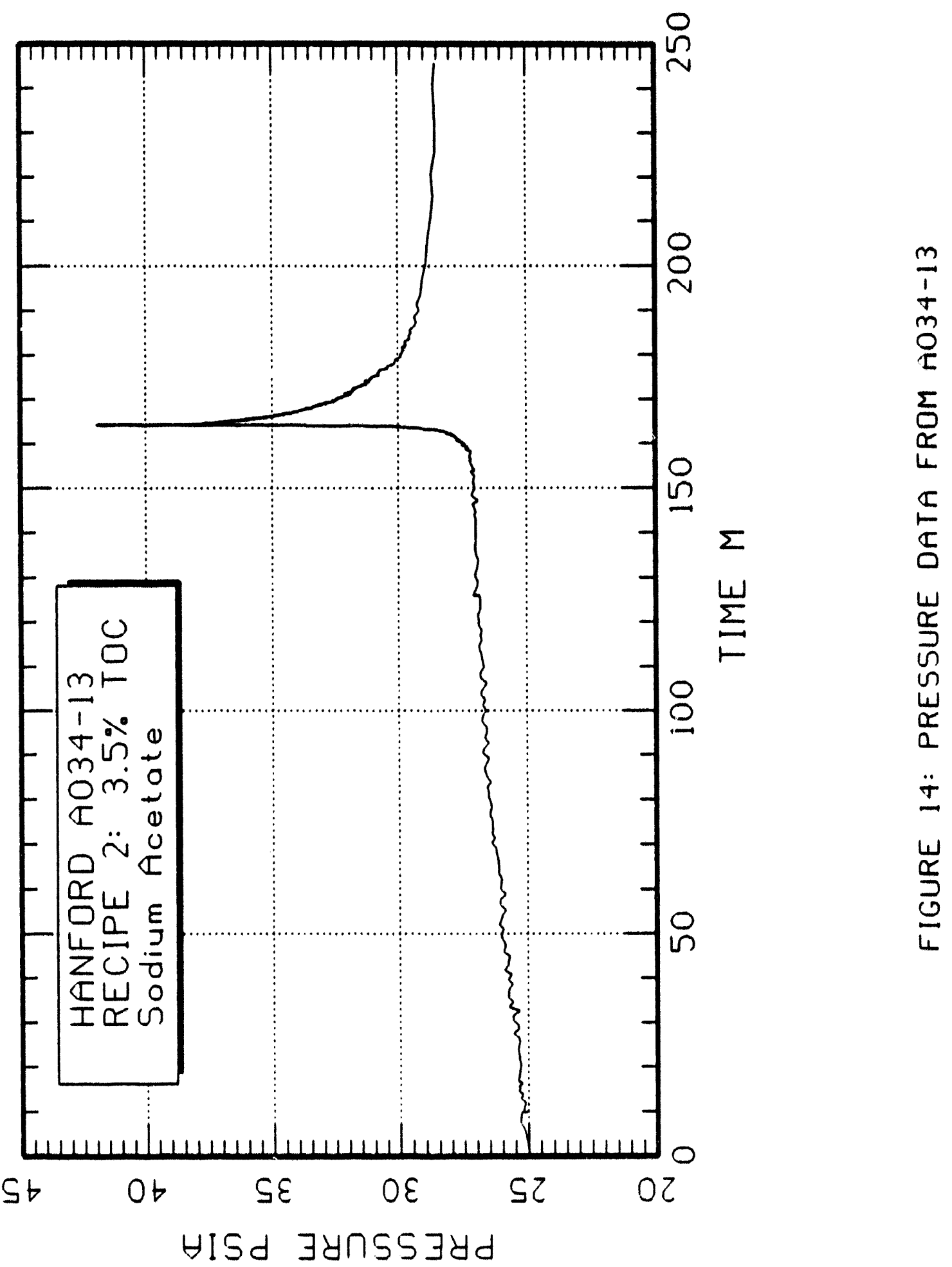




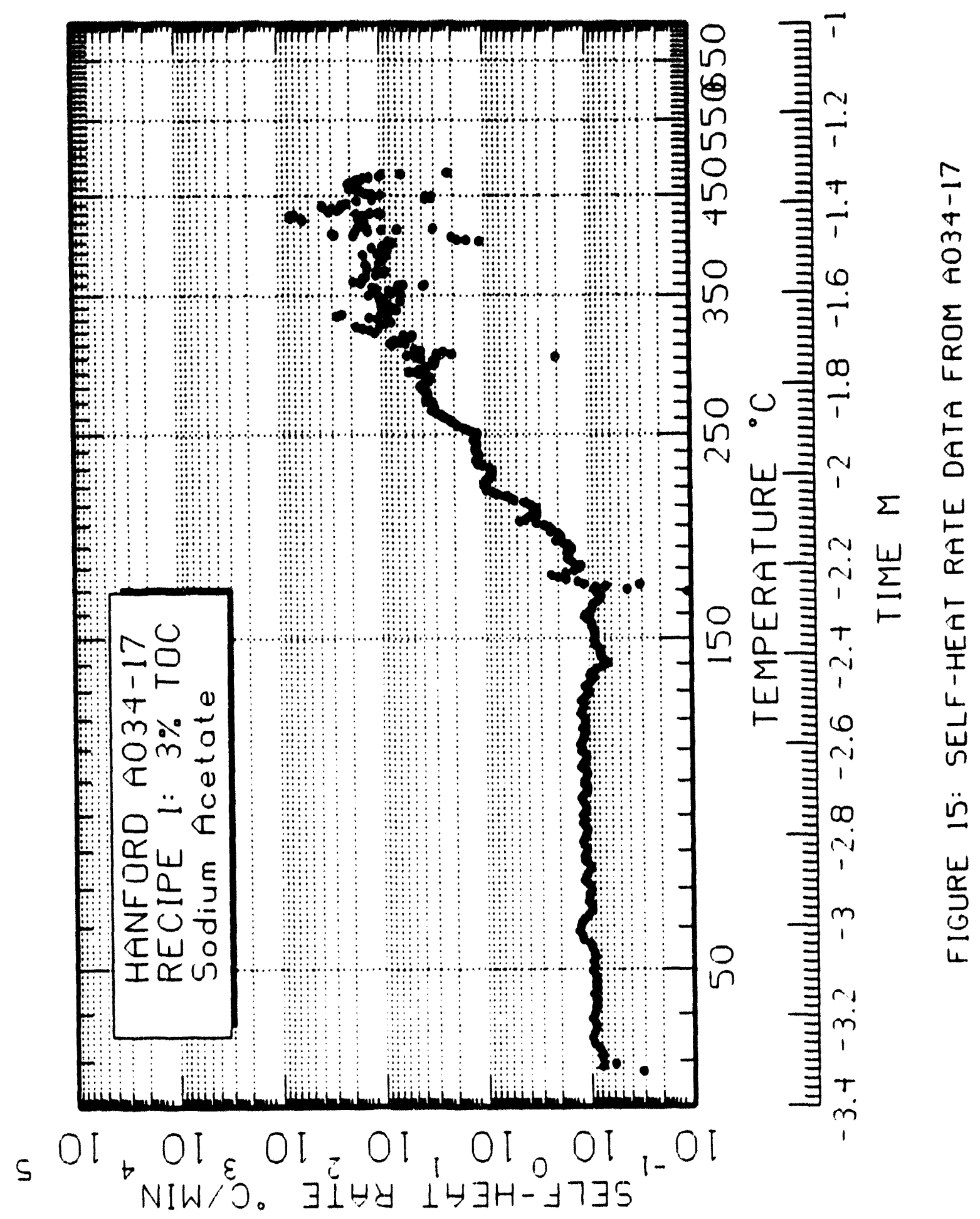




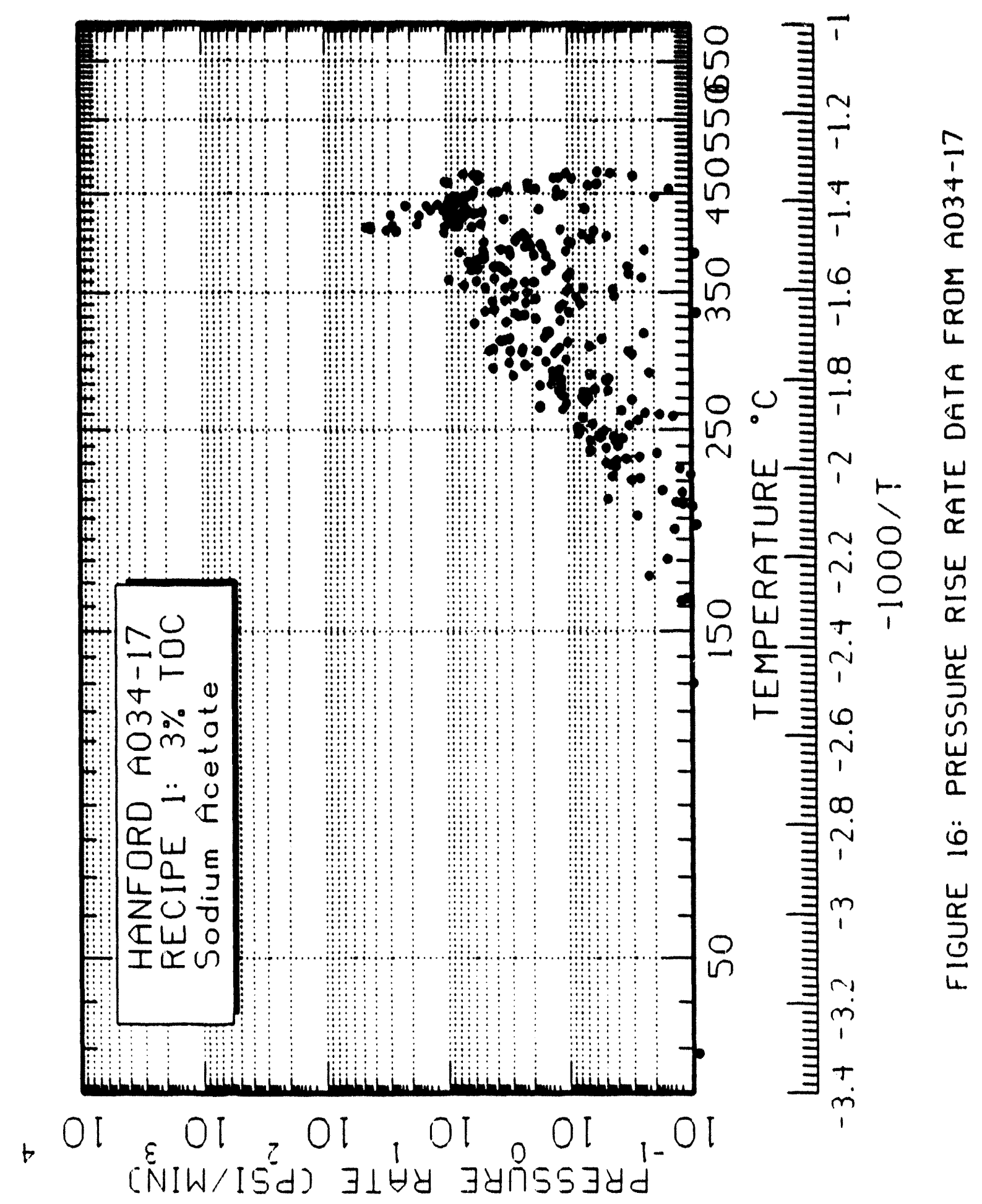




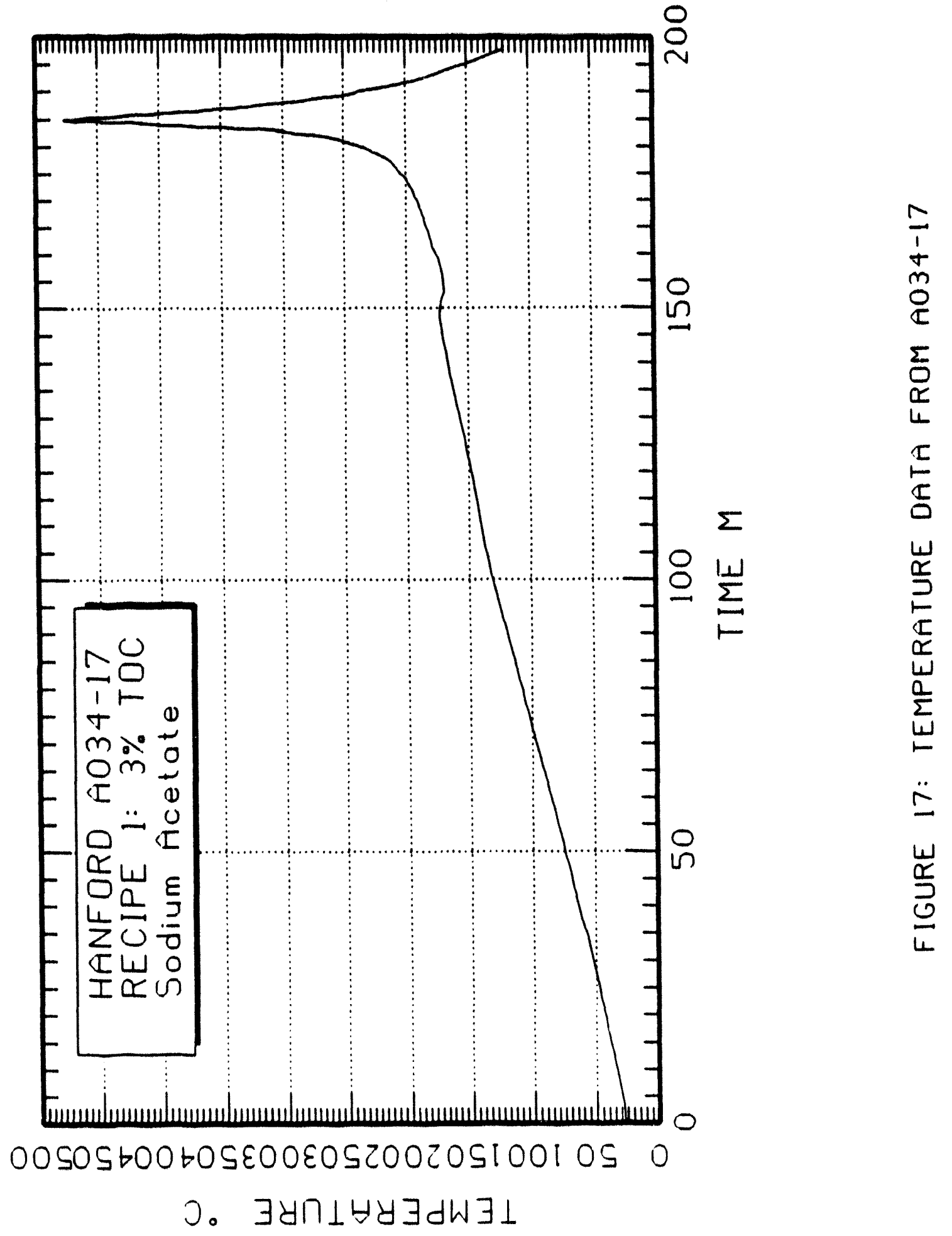




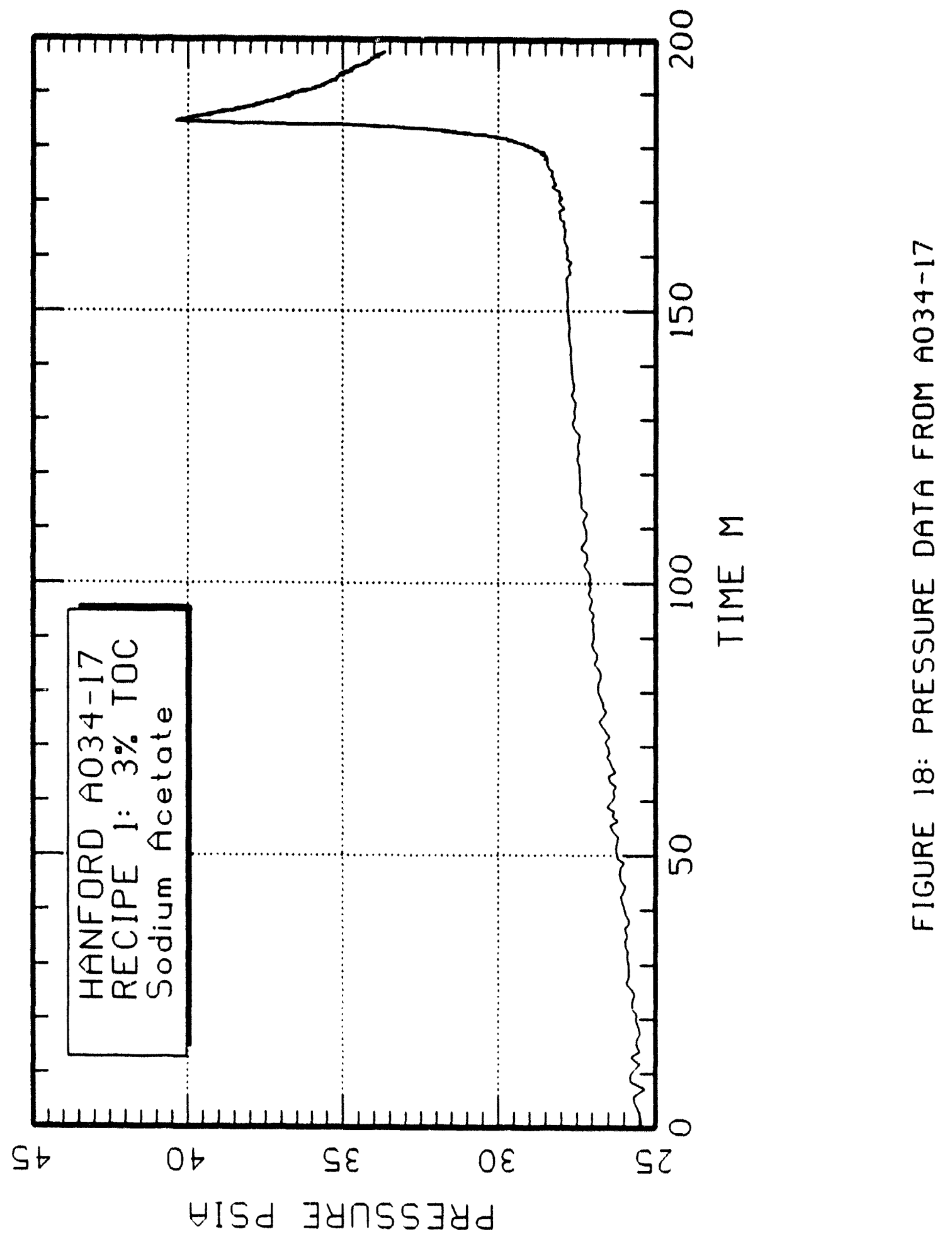




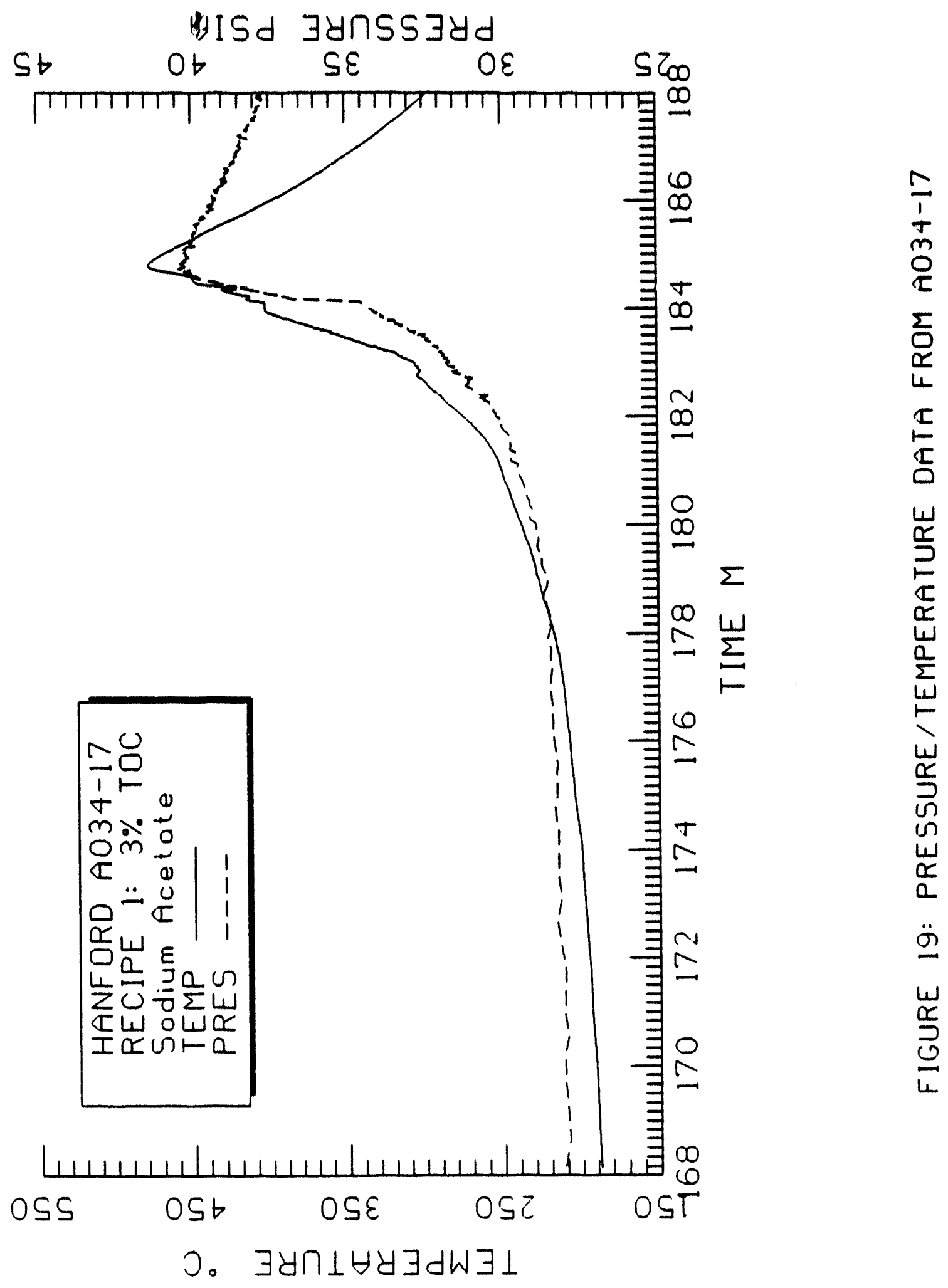


Assuning onset of exothermic activity at about $180^{\circ} \mathrm{C}$, results in a measured temperature rise of about $305^{\circ} \mathrm{C}$ and a heat of reaction value of ajout 2.9 $\mathrm{MJ}$ per $\mathrm{kg}$ of sodium acetate.

Post-test examination following cooldown indicated similar behavior to that noted for RSST tests with 3.5 and 5 wi TOC.

VSP - 3 w TOC (Reclpe 1 in the Subject Reference)

A $60.29 \mathrm{gm} 3$ wo TOC sample (10.4 wo sodium acetate, 5.4 wo sodium hydroxide, 67.5 wo sodium nitrate and 16.7 wo sodium nitrite) was prepared and loaded in the VSP test cell, using the same procedures as noted for RSST test - 7 wo TOC. The subject test was carried out with the objective of measuring the adiabatic temperature rise to more accurately determine the heat of reaction associated with the exothermic activity.

The measured VSP data are presented in Figures 20 through 23 . The general trends of the data are consistent with the corresponding RSST tests. Due to the VSP capability of accommodating endothermic behavior, noticeable exothermic activity is not suggested before about $200^{\circ} \mathrm{C}$. Using this as the reference temperature, an adiabatic temperature rise of about $370^{\circ} \mathrm{C}$ is indicated with a peak temperature of $570^{\circ} \mathrm{C}$. Both the RSST and the VSP tests indicate peak rates of about $200^{\circ} \mathrm{C} / \mathrm{min}$, but the peak temperature measured with the RSST test is about $475^{\circ} \mathrm{C}$ as compared to $570^{\circ} \mathrm{C}$ with the VSP test. This difference can be related to the much larger time constant for the VSP sample, allowing the larger sample to more closely approach adiabatic heatup conditions (i.e., the time constant is large compared with the time associated with the noted temperature rise). On this basis we estimate a heat reaction of about $3.7 \mathrm{MJ}$ per $\mathrm{kg}$ of sodium acetate using a heat capacity value of $1000 \mathrm{~J} \mathrm{~kg}^{-1} \mathrm{~K}^{-1}$.

The net pressure gain following cooldown in the VSP containment vessel $(3.75 \mathrm{l})$ was $10 \mathrm{psi}$ which corresponds to a gas production of 0.11 moles. This compares to the theoretical value of about 0.12 moles. Post-test examination of the VSP containment vessel indicated similar hehavior to that observed with RSST tests $3,3.5$ and 5 wo TOC. 


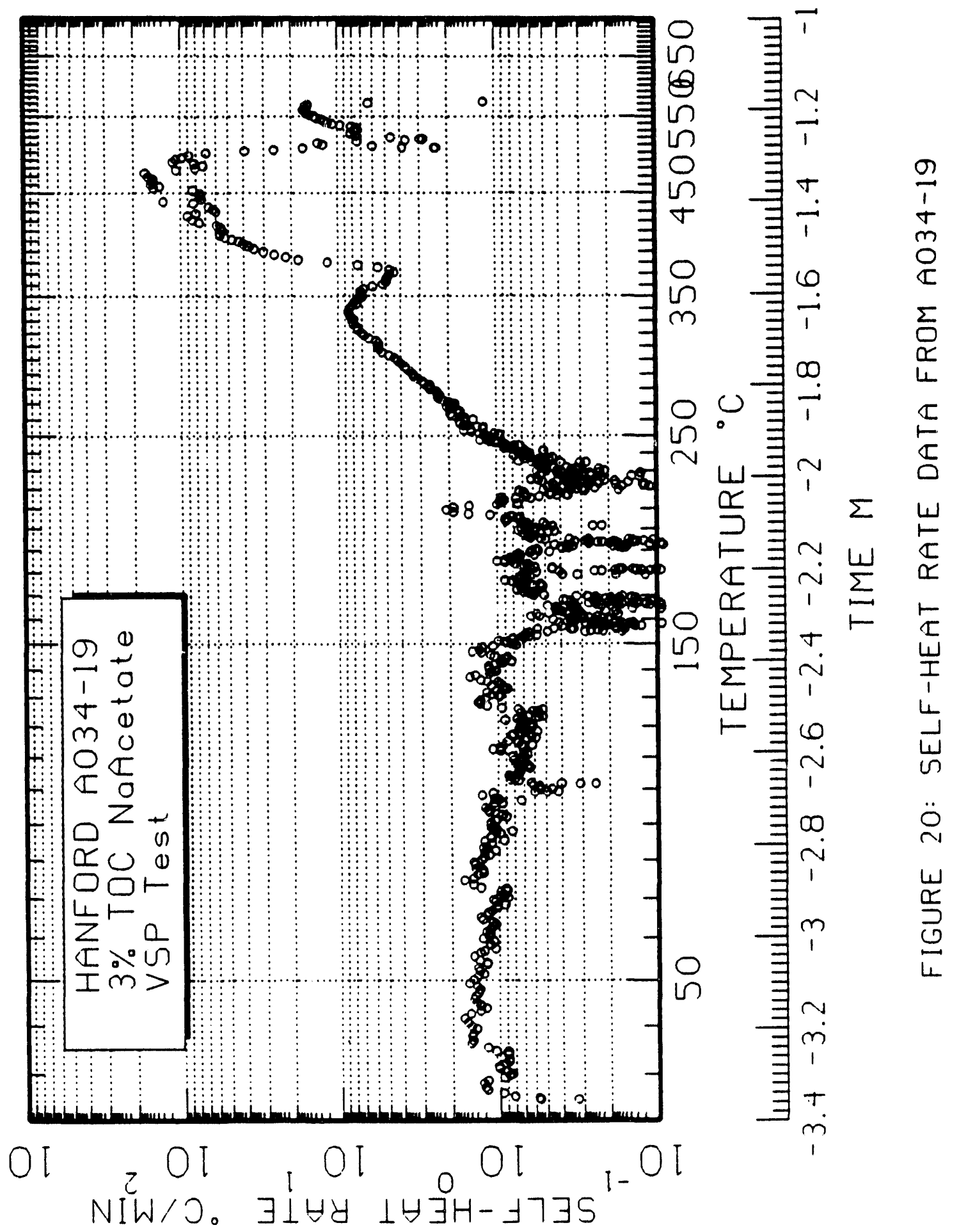




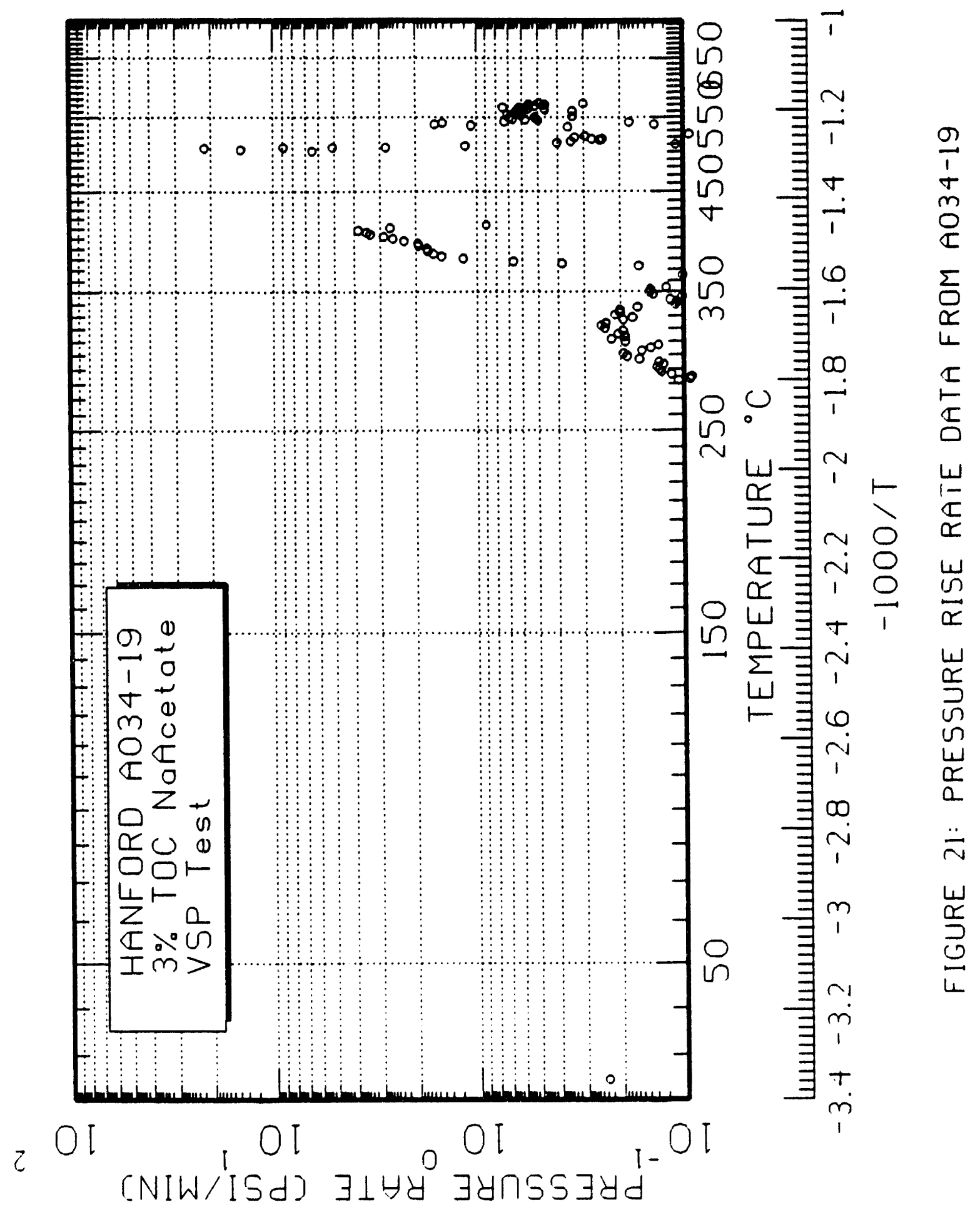




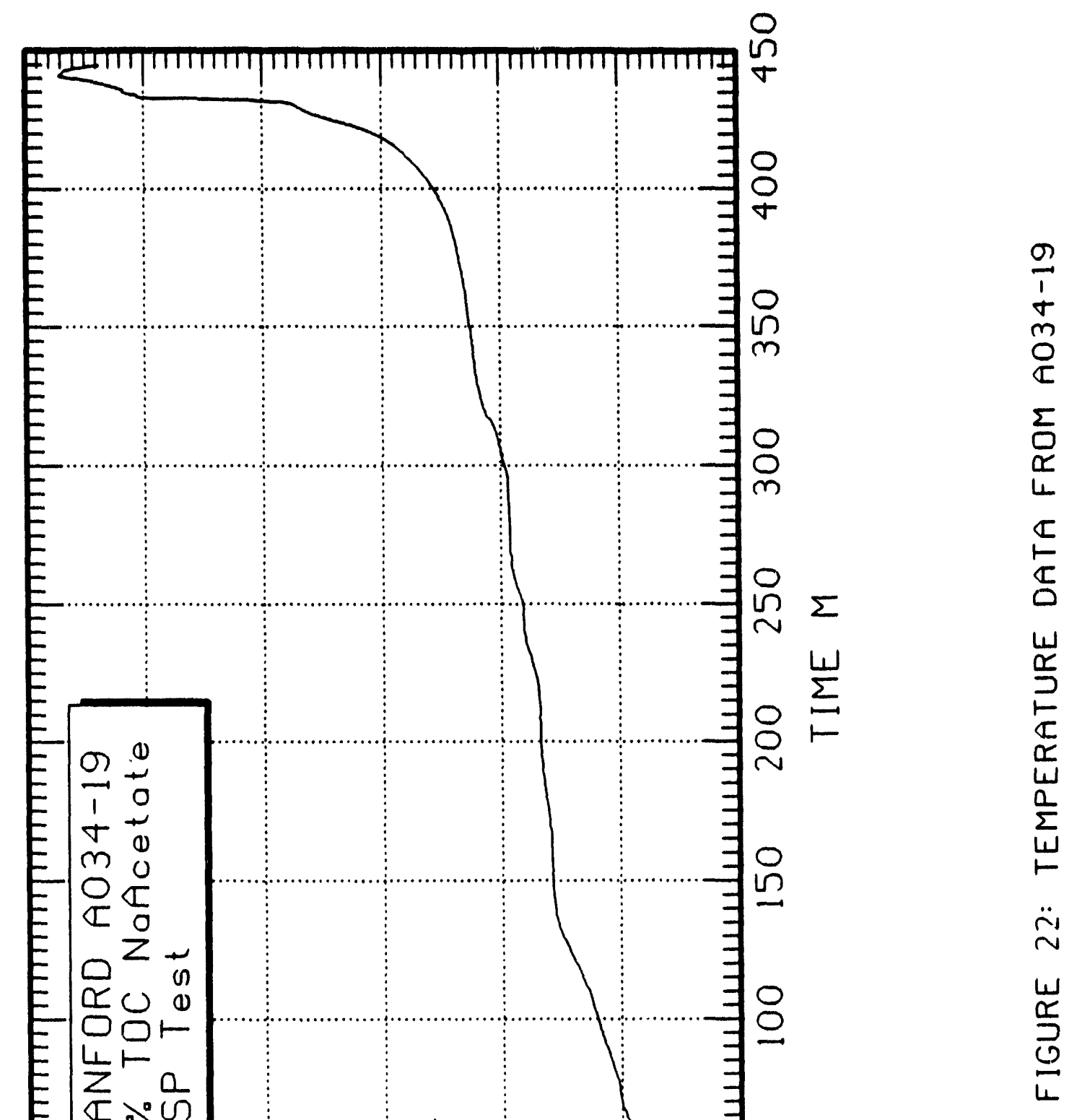




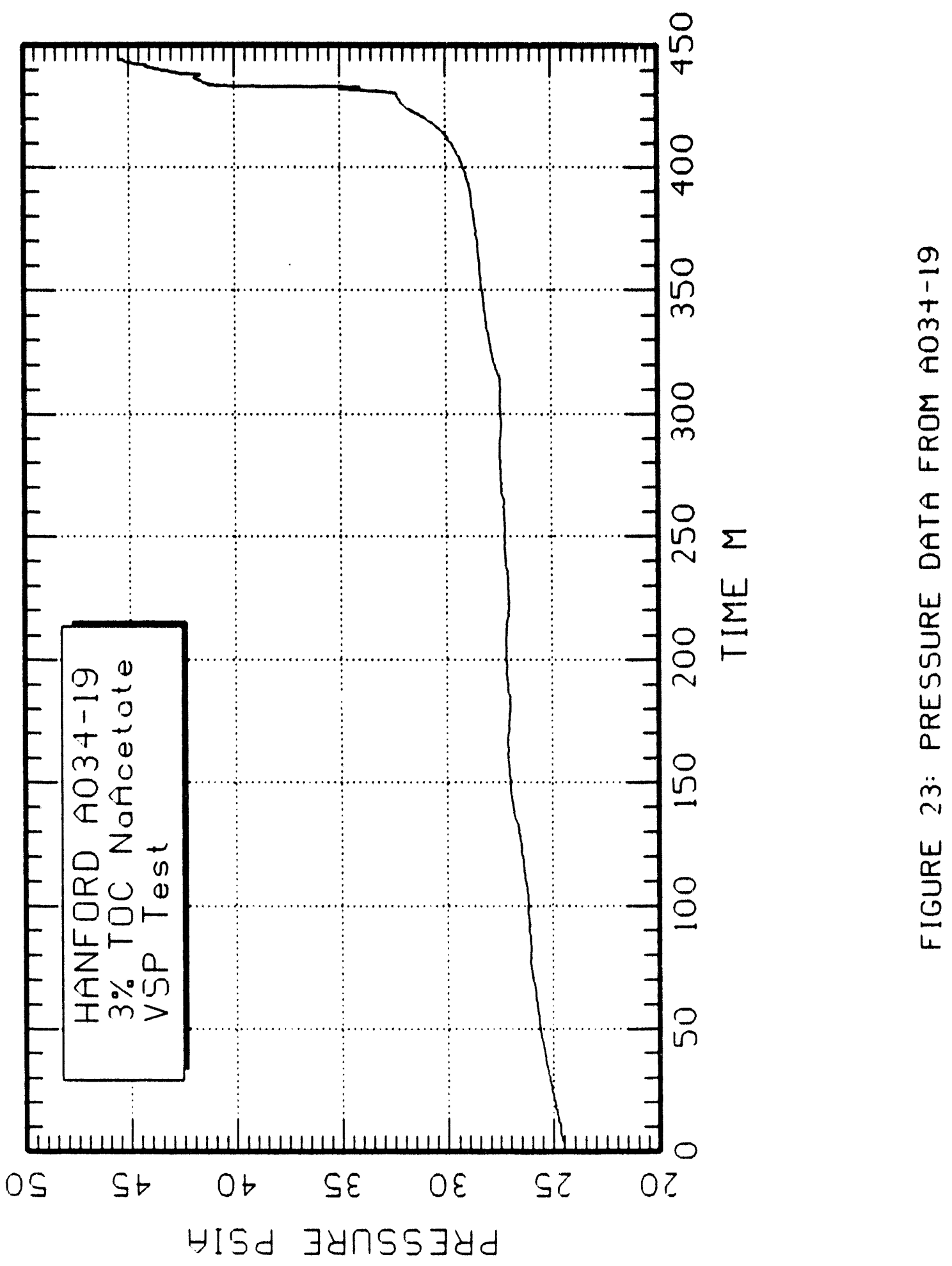




\section{Dhanasion}

Based upon the above observations, It is of interest to estimate the necessary welght fraction of water that would prevent a propagating reac. tion with a speclfied acetate-nitrate mixture given the presence of an ignition source. Accounting for sensible as well as latent heat of vaporization due to the presence of water, we can estimate the waight fraction water that would prevent propagation from

$$
\begin{aligned}
& x_{H_{2} O}>\frac{N}{1+N} \\
& N=\frac{\left(x-x_{n}\right) \Delta H_{R}-C_{M}\left(T_{0}-T_{1}\right)}{\lambda+C_{H_{2} O}\left(T_{B}-T_{1}\right)}
\end{aligned}
$$

where $x$

- welght fraction of fuel (sodium acetate) in a dry mixture,

$$
\begin{aligned}
& x_{\mathrm{N}} \text { - estimated weight fraction of fuel (sodium } \\
& C_{M}\left(\mathrm{~J} \mathrm{~kg}^{-1} \mathrm{~K}^{-1}\right) \text { - specific heat of dry sample }\left(-1000 \mathrm{~J} \mathrm{~kg}^{-1} \mathrm{~K}^{-1}\right) \text {, } \\
& T_{0}(K) \quad \text { - onset temperature for propagating reaction (- } \\
& T_{i} \text { (K) - waste tank operating temperature (- } 323 \mathrm{~K} \text { ), } \\
& \lambda\left(\mathrm{J} \mathrm{kg}^{-1}\right) \quad-\underset{k g}{l a t p n t} \text {, heat of vaporization }\left(-2.25 \cdot 10^{\circ} \mathrm{J}\right. \\
& \mathrm{C}_{\mathrm{H}_{2} \mathrm{O}}\left(\mathrm{J} \mathrm{kg}^{-1} \mathrm{~K}^{-1}\right) \text { - speciflc heat of water }\left(-4300 \mathrm{~J} \mathrm{~kg}^{-1} \mathrm{~K}^{-1}\right) \text {, and }
\end{aligned}
$$

\footnotetext{
*The 0.2 value simply represents the average between 5 wr TOC and 7 wo TOC. Recall that the 5 wo TOC test did not exhibit a propagating reaction while 7 wo TOC test did.
} 


$$
T_{B}(K) \quad-\text { bolling temperature of waste }(-403 K) \text {. }
$$

Based upon the above parametera, we calculate the necessary walght fraction of water or molsture to prevent a etolchlometric mixture (- 38 wo sodium acetate or 11 we TOC, and 62 we sodlun nitrate) from propagating given an Ignition source to be only about 0.14 (14 w/), suggesting that propagating reactions in the Hanford tank environment can be ruled out. Additioral adlabatic calorimetry tests using sodium oxalate and sodium stearate representing the organic fuel are being planned to further conflrm the above observation.

HKF: Jal

At tachments

cc: R. J. Cash, WHC

D. W. Jeppson, WHC 


\section{DISTRIBUTION}

\section{Number of Cootes}

\section{ONSITE}

1

1

26
Y.S. Dapartment of Enoeray. Rtchland Field offtes
Pubtic Reading Room Al-65

MACTEC

S. T. Murff

R3-82

Battalle Pacifle Northwest Laboratories PNL Technical flles

K1-11

Mestinghouse Hanford Comoany

K. O. Fowler

R2-78

$R 2-78$

R2-31

C. Defigh-Price

K. A. Gasper

J. C. Fuiton

D. A. Turner

N. H. Kirch

G. A. Hanson

M. A. Islan

J. M. Grigsby

A. Postma

R. J. Cash

J. W. Osborne

G. D. Johnson

W. T. Alumkal

H. D. Harmon

E. P. Vodney

P. R. Praetorius

D. C. Board

M. A. Cahill

Document Processing and Distribution (2) Central files

Information Release Administration (3)
R2-08

R2-31

$R 2-78$

R2-11

T3-03

H5-53

H4-62

H4-62

R2-78

S4-60

R2-78

R2-52

R2-52

B3-50

GI-63

S1-57

61-67

L8-15

L8-04

R1-08 

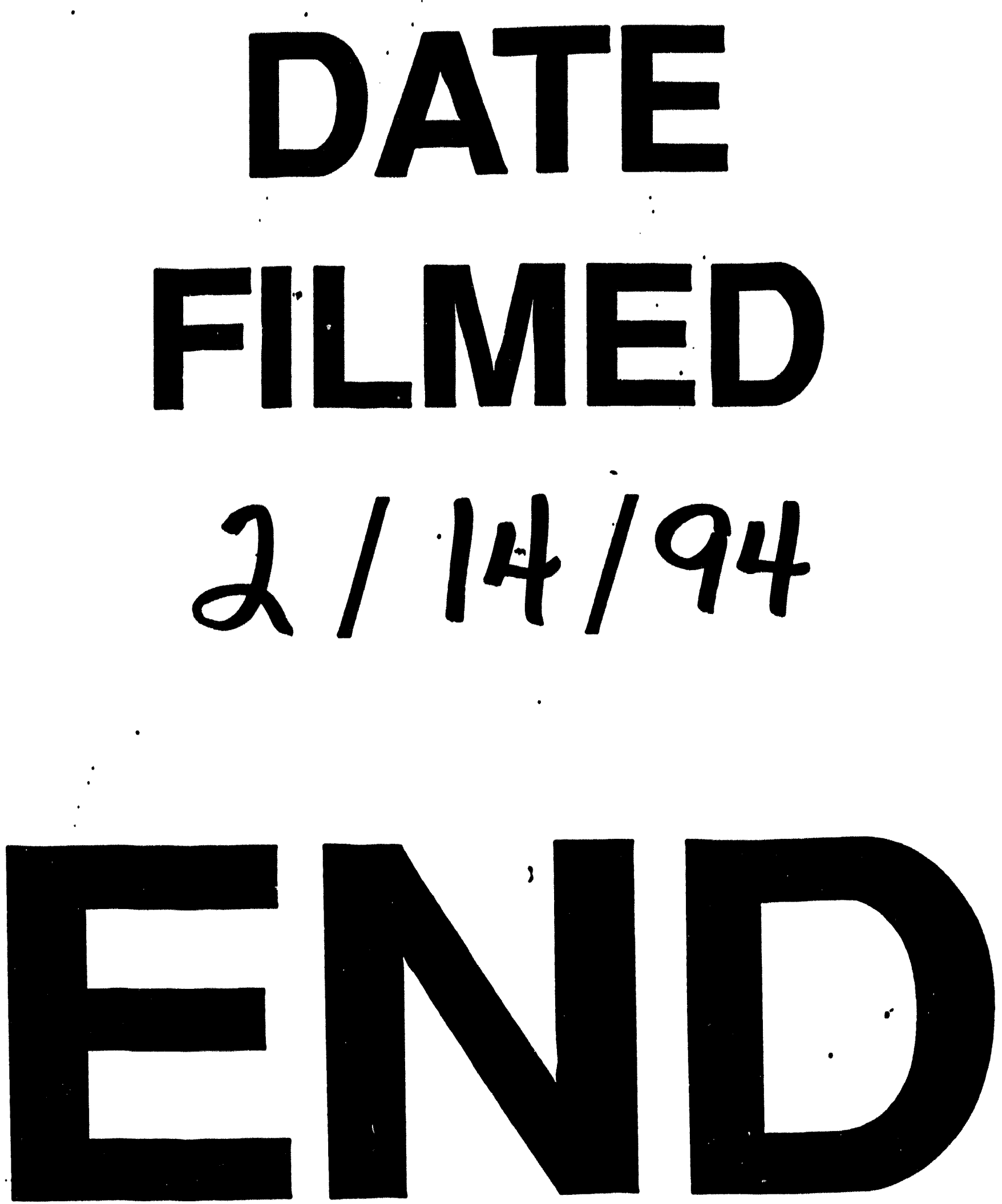


$$
-
$$

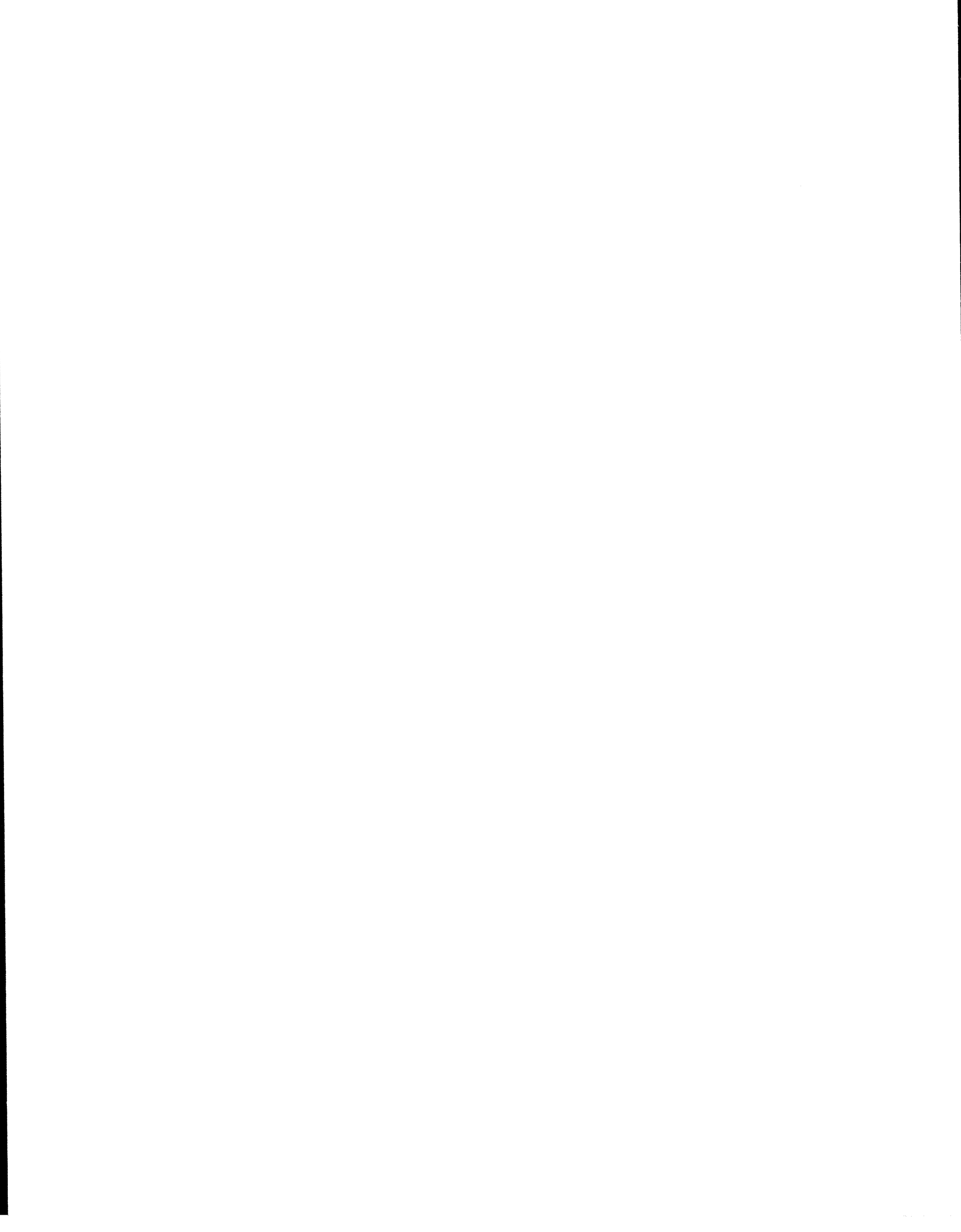

